\title{
Iglesia y Economía en el Perú durante el Siglo XVIII
}

\section{Por Pablo Macera Dall'Orso}

¿Cuál fue en el Perú durante el siglo XVIII la posición ideológica de la Iglesia frente a la vida económica? A esta sola pregunta, y todavía con algunas limitaciones, pretendo responder en este ensayo. Debo adverlír pues, a riesgo de una redundancia, que no se ha de buscar aquí ni una historia de la Iglesia ni una historia de la economía; sino un esbozo de la imagen que la Iglesia se había formado de aquella economía. Por esta vía indirecta estaremos en condición de preguntar más tarde acerca de a) la actividad económica de la Iglesia a la cual aludo en la Segunda Parte de este trabajo; b) la influencia de esa actividad y de su ideología correspondiente en el conjunto del proceso social. Sólo entonces averigúaremos lac sinvez Cómöese proceso determinó la conducta económica de la Iglesia; entendiendo por conducta tanto el comportamiento práctico y real como la postura ideológica. De esa investigación circular presento ahora el primer aspecto; escogido en parte quizás arbitrariamente (pues en teoría se hubiera podido comenzar por cualquiera de los otros); y en parte como introducción a un estudio sobre el modernismo peruano del siglo XVIII.

[Creo además que el conocimiento de la actitud ideológica de la Iglesia contribuirá a la discusión sobre si hubo o no una "ideología burguesa" y una "clase burguesa" en el Perú del siglo XVIII. Particularmente en lo que toca a fenómenos como la Ilustración y la Independencia. Tanto en España como en el Perú se ha sostenido en los últimos años que el movimiento emancipador fué un movimiento burgues ${ }^{1}$. 'Para decidir sinembargo acerca de esas hipótesis, precisa antes que nada estudiar las diversas clases sociales de la colonia; determinar sus estatutos económicos, pedagógicos, religiosos, etc....; y comparar sus tenden- 
cias doctrinales y aspiraciones con el programa de las rebeliones que culminaron en la campaña libertadora de 1820-1824. Las mismas atingencias son extensivas al "pensamiento moderno" del siglo XVIII y a la medida en que entonces intervino una supuesta burguesía. En el curso de esas investigaciones se habrá de esclarecer si el pensamiento y la acción social de la Iglesia Católica suministraron en el Perú algunos elementos formativos a la visión burguesa del mundo; o cuándo y porque la combatieron ${ }^{2}$ ].

Cualquiera que frecuente la literatura eclesiástica peruana del siglo XVIII puede comprobar la insistencia con la cual sus autores mencionaban y juzgaban la vida cotidiana. Toda acción suponía para ellos una ofensa o una alabanza a Dios; lo secular era referido al plano religioso. La Iglesia pretendía dirigir minuciosamente las ocupaciones temporales del católico. Moralizar el mundo para que la Ciudad de Dios surgiese según pedía un predicador criollo en el interior de la Ciudad de los hombres, como una obra de santificación. En esta valoración religiosa de la existencia no podían faltar desde luego normas e imágenes explícitas sobre las actividades económicas. Todavía más; después de la vida sexual y de la "corrupción de las costumbres", los temas del rico y el pobre, el lucro, pereza, trabajo, usura, etc.... fueron los más frecuentes en los sermones y pastorales del siglo XVIII ${ }^{3}$.

En sus líneas Benerales esas definiciones eclesiásticas de lo económico fueron semejantes crirel Perúdelesiglo XVIII a las que se pueden encontrar en otras regiones y períodos de la Iglesia considerada como sociedad universal. Se podría hablar así en nuestro caso de un criterio y un contenido tradicionales de la doctrina social católica. Con algunas variantes hay cierta continuidad entre las pastorales del virrey arzobispo Ladrón de Guevara (fines del siglo XVII) y las del realista Sánchez Rangel escritas en el período de la Independencia; y aun más lejos entre ellas y las quejas del obispo Moreyra contra los cambios sociales instaurados por la República (1868) y las disertaciones del franciscano Gual (1813-1890) contra el liberalismo, los Krausistas y la doctrina de Marx ${ }^{4}$. Más, a lado de esta aparente intemporalidad y universalidad de la doctrina (aparente puesto que lo decisivo es la circunstancia a la cual se aplicaba), conviene apreciar los rasgos particulares adoptados por ese cuerpo de ideas en el último siglo del coloniaje. El cristianismo como religión encarnada, en un tiem- 
po y un lugar concretos, fue sensible a las infiluencias de la sociedad secular ${ }^{5}$. El análisis de esas inflexiones sociales de la ideología económica de la Iglesia nos muestra en todo el curso del siglo XVIII la presencia de elementos foráneos, profanos, que se yuxtaponen o mezclan con los tradicionales del catolicismo.

En esta breve reseña no hay el tiempo suficiente para ensayar una clasificación ni una cronología de esos elementos seculares. Nos basta reconocer por ahora que los más decisivos fueron aquellos que provisionalmente calificaremos como elementos modernos; es decir como esquemas y sugerencias que provenían del racionalismo ilustrado, trasplantado de Europa al Perú y difundido desde mediados del siglo XVIII entre los eclesiásticos cultos y las laicos de las clases dirigenies. En la teología como en la oratoria sagrada y el culto se produjo entonces el mismo fenómeno de confrontación, el mismo ensayo de síntesis entre la religión católica y el modernismo que caracterizan a las imágenes y valoraciones económicas de la Iglesia ". Singretismo que determinó al mismo tiempo el contenido de los temas como de otra parte las estructuras de la inteligencia y de la sensibilidad '. Sería necesario aquí señalar las correspondencias muy estrechas que existían entre la posición de Gonzales Laguna, Ignacio de Casiro, etc... . que consideraban a las ciencias profanas como auxiliares de la religión y de la teología; las condenaciones del barroco en nombre de una nueva "sencillez racional" de la arquitectura y la oratoria (Sánchez, Ruiz Cano' Bermủdez); lla chífican de llos falsos milagros y de las supersticiones (Bravo de Lagunas, Rodríguez de Mendoza, Rossi); y en lo que se refiere a nuestro estudio la aparición de argumentos supletorios de tipo racionalista y profano para apoyar las interpretaciones económicas tradicionales del catolicismo ${ }^{8}$.

En fin, para juzgar en forma completa las relaciones entre la ideología económica eclesiástica y las ideologías laicas, agreguemos que las influencias fueron recíprocas; y que los laicos tomaron prestado del pensamiento religioso argumentos, ejemplos, normas, que reforzaban sus propias convicciones. Son los casos, entre otros, de las críticas contra el monopolio (Borda), la usura y la carestía del numerario, la ociosidad (Lequanda), el celibato eclesiástico como causa y síntoma de la decadencia demográfica (Pezet); $y$ en todos los cuales el economista peruano del siglo XVIII y principios del XIX se sirvió del catolicismo tanto o más que de las ideas modernas. 
Cada uno de esos problemas, de esas influencias mutuas, merecería un estudio aparte. En las páginas que siguen apenas si se podrán encontrar examinados algunos de ellos. Muchas veces no hemos averiguado si determinados conceptos o valoraciones usados por la Iglesia provenían de los medios laicos o de las tradiciones bíblicas. Y menos aun si en algunos casos puede llegarse a decir que la Iglesia quiso favorecer a ciertos grupos sociales ${ }^{\theta}$. La intención es otra: servirnos de los propios testimonios eclesiásticos a fin de poder ver a la vida económica peruana del siglo XVIII (cor lo menos algunos de sus aspectos esenciales) con los mismos ojos con que la Iglesia esperaba que la viese un buen católico de entonces.

\section{La idèologia.}

a) el trabajo.- 1. Según la Iglesia Católica el trabajo constituía el primer fundamento de la actividad económica. El hombre aunque redimido por la crucifixión seguía purgando con su trabajo el pecado de los primeros padres; por tanto, el trabajo era no sólo una institución social sino un mandato divino; castigo, virtud, ley. Para los predicadores y prelados peruanos del siglo XVIII el vicio opuesto -la pereza - fue siempre uno de los pecados más graves porque precisamente, entre otras razones, implicaba una rebelión contra Dios. "El que quisiere tener el sustento de su cuerpo y los bienes debalma con bendiciones de Dios, decía un texto de principios del siglo XVIII, trabaje destierre el ocio y la pereza; luche y pelee contra esos -vicios y los desterrafá a ellos y a los demás que nacen con ellos" ${ }^{10}$. La Iglesia no disculpaba al ocioso ni consentía en que éste la invocara como pretexto para huir de las penalidades del trabajo. Lo prueban sus reiteradas declaraciones contra la falsa caridad ${ }^{11}$ y las falsas vocaciones religiosas ${ }^{12}$; la reforma de los días festivos ${ }^{13} \circ$ su apoyo a los particulares (Ladrón de Guevara 1745) que proyectaban nuevas ocupaciones para el pueblo ${ }^{14}$.

Contra los que sugerían veladamente, como José Pezet, que la religión católica entorpecía el desarrollo económico ${ }^{15}$, la Iglesia respondía que aparte de sus elogios al trabajo, ella había insistido en que la ley evangélica no era opuesta a las conveniencias civiles. Aquello que fuera exigido por el orden público, lo exigía también la doctrina católica, pues según el canónigo Echague (1825), si bien la Religión "eleva nuestros pensamientos al cielo y finca la esperanza en su eterno galardón, se complace (tam- 
bién) en el ejercicio de las virtudes sociales, de aquellas nobles afecciones a que está vinculado el bien de la humanidad" 16. Esta posición no varió en todo el curso de los siglos XVIII-XIX y en todos los sectores eclesiásticos, cualquiera que fuese su actitud política ○ filosófica (tradicionales, modernos, partidarios de la Independencia $\circ$ del Rey). En ningún momento se estableció una distinción neta entre el plano religioso y el plano secular. El cristianismo como religión oficial de un régimen teocrático hacía suyos los intereses del Estado y los de la Sociedad que ese Estado dirigía. Si en el orden político, la obediencia era un deber al mismo tiempo religioso que civil; el trabajo, en lo económico merecía igualmente esa doble consagración. El más reaccionario y conservador de todos los obispos españoles del Perú. Hipólito Sánchez Rangel, no era al respecto menos explícito que Echague colaborador de los patriotas:

Echague; Lima 1825. "La Ley del Evangelio no mira con indiferencia la pereza del ciudadano; condena antes bien al siervo inútil, pronta a recompensar al que emplea sus brazos en beneficio de la sociedad. El trabajo merece sus bendiciones, y el operario que vuelve duplicados los Talentos que el Señor le había confiado, es establecido sobre muchos más: mientras que castiga la inacción del que ocultando el que se le había concedido, se niega aún a síl mismo el fruto de su industria: En la parábola del padre de familia, que necesitaba para cultivarestu vida, convocaval16s "operarios, les ofrece premios, estimulándolos a que no permanezcan ociosos. La austeridad de los principios evangélicos no separa al cristianismo de las ocupaciones industriosas que prescribe la sociedad, y santifica la virtud; el orden público exige con justicia su actividad y reprueba el abandono que ocasiona la indolencia; y la religión lejos de desdeñar las distinciones y altos empleos merecidos, en retribución de los sacrificios individuales, los aprueba y confirma; porque si bien eleva nuestro pensamiento al cielo y finca la esperanza en su eterno galardón, se complace en el ejercicio de las virtudes sociales, de aquellas nobles afecciones a que está vinculado el bien de la humanidad".

\section{Sánchez Rangel; Maynas-Madrid 1825.}

"La Ley de Dios no prohibe divertirse a ciertos tiempos, pero manda en ello moderación, la honestidad y que no perdamos de vista nuestro último fin. No pro- 
hibe que cojais los frutos que os presenta en estas tieras la madre naturaleza, ni que comercies con ellos; y ojalá que fomentarais este ramo para vuestra utilidad y la de estos reinos; pero manda que os abstengais de la codicia y ambición contentos como San Pablo con lo muy preciso para comer y vestir decentemente y que asistais con lo sobrante a los hermanos necesitados... manda que si comercias no sea perjudicando al prójimo, sino aliviándolo por este medio... Divertiros, trabajad y comerciad enhorabuena para vosotros y vuestros hijos, pero por caminos recios y lícitos y sin olvidarse de la muerte" 17 .

Adviértase que Sánchez Rangel limitaba los frutos del trabajo a lo estrictamente indispensable para el sustento, reprobando ya no la codicia sino también el simple enriquecimiento y la elevación de una clase social a otra ("No querais... ser en el mundo más que aquello que quiere Dios que seais naturalmente, conforme a vuestro nacimiento y proporciones"). De modo tal que el villano fuera siempre un yillano, el caballero, un hidalgo y que todos y cada uno se resignaran a un orden social, quizás defectuoso - lo cual no examinaba Sánchez Rangel- pero establecido indirectamente por Dios ${ }^{1 S .}$ El hombre no debía "querer ser más" en este mundo sino en el otro; competir en santidad y no en riquezas. Echague a su vez declaraba que la Religión confirmaba las distinciones y altos] empleos (las jerarquías sociales) aunque para él esas jerarquías fuesen una retribución a los sacrificios individuales, ¿un honor al mérito y no un privilegio de la herencia? Como correspondía a un sacerdote colaborador de los "patriotas", es decir de un grupo seudo-revolucionario que no quería destruir verdaderamente al coloniaje -el coloniaje sobre el indio- ni al régimen de explotación económica, sinó gozar de ellos más a sus anchas, suplantando al español. Ninguno de ellos -el realista $\circ$ el patriota - aparecía como partidario de una sociedad regida exclusivamente por el mérito de la producción económica, del trabajo o del trabajador, del productor que ellos elogiaban. El trabajo debía conservar-pero no transformar las jerarquías sociales. Nosotros no podemos comprender estas reservas y estas timideces como una falla del razonamiento ni tampoco como una desviación del ascetismo cristiano que prohibía el afán de lucro. El ideario económico de la Iglesia reflejaba en este aspecto sus compromisos temporales y su unión estrechísima con las clases privilegiadas a las que pertenecían sus prelados y gran parte del clero; y se ins- 
cribía en los cuadros más amplios de una sociedad relativamente inmóvil -o que aspiraba a la inmovilidad vertical de sus grupos sociales. Favorecía por tanto a todos aquellos hombres para quienes una tansformación cualquiera hubiese significado en la práctica una liquidación de sus privilegios.

A esas limitaciones se agregaba en la imagen económica eclesiástica, la imprecisión en los terminos. La Iglesia no definía claramente lo que ella entendía por trabajo y por trabajador. A su juicio todos los hombres trabajaban -o debían trabajar- ya que como hemos dicho antes, todos los hombres habían recibido el trabajo como un castigo divino. Dentro de esa categoría general y abstracta del trabajo la Iglesia no diferenciaba los diversos tipos de ocupación. Es cierto que nosotros encontramos en los textos de la época descripciones minuciosas de los "oficios mecánicos y serviles" y que algunas veces (el arzobispo Liñán y Cisneros 1697) se exigió por parte de la iglesia una "humanización" del género de vida, del trabajo, que realizaban los indios o los negros esclavos de las haciendas. Mas en ningún caso esas descripciones y exigencias particulares se organizaron en una visión de conjunto que clasificara al trabajo; fuese según el punto de vista estrictamente cristiano (ambivalencia castigo-virtud), fuese de acuerdo a la naturaleza del esfuerzo realizado, al rendimiento y a las necesidades económiças. La Iglesia sustituía tácitamente esas omisiones a través de su concepción de las jerarquias sociales (concep-

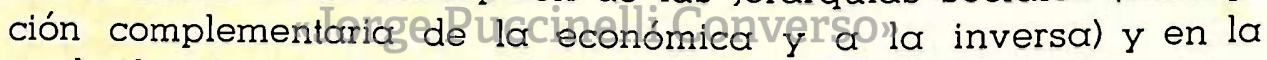
cual, el trabajo - fundamento de la economía - se transformaba en un elemento subalterno, de menor importancia que muchos otros, entre ellos la herencia. En vez pues de una consideración autónoma (religiosa y/o económica) del trabajo, la Iglesia se remitía a un orden diferente de ideas y de valores: la jerarquía del trabajo debía seguir a la jerarquía de las clases; copiarlas y someterse; las ocupaciones de la plebe eran en consecuencia necesariamente inferiores a las ocupaciones de la nobleza, cualquiera que fuese la utilidad social objetiva de cada una de ellas. Mediante ese procedimiento la ideología eclesiástica evitaba la irrupción en el plano social de valoraciones peligrosas, utópicas, extrañas a las habituales en el coloniaje. Imaginemos simplemente lo que hubiera significado que la Iglesia hubiese propuesto en el siglo XVIII que las jerarquías sociales se organizaron en función del trabajo y no al revés. 
[La defensa de los privilegios sociales de las clases dirigentes en el interior de una imagen estática de la sociedad fué muy común en el siglo XVIII y no sólo en los medios eclesiásticos. Los escritores modernistas (El Mercurio Peruano) pretendieron reemplazar el nacimiento por la inteligencia en la organización de las jerarquías -porque ellos se consideraban poseedores de la inteligencia- pero sólo fueron partidarios -de una movilidad social restringida y gradual en favor de su grupo. Calificaban a la igualación de las clases de "quimera", "creación diabólica de los falsos filósofos", etc... Feyjóo decía -y todos los modernistas peruanos fueron grandes y entusiastas lectores de Feyjóo- que los saltos de fortuna eran dañinos para el hombre. "Malos son los de arriba a abajo porque despedazan la honra y la hacienda; pero peores los de abajo a arriba porque comúnmente destruyen el alma"; y en sus Paradojas Políticas y Morales agregaba que para hacer más clara y constante la división de clases en la República, los oficios debían ser hereditarios de padres a hijos. Las jerarquías sociales eran intangibles, puesto que 'a sociedad humana reproducía la celestial (Soto y Marne) y que las diferencias entre los hombres se debían a la Providencia y no a la fortuna o al azar pagano 1\%. De ahí que una de las metáforas más usuales fuese la de la comparación entre el cuerpo humano y el cuerpo político, a fin de probar que este último como el primero poseía "órganos" y funciones invariables en una jerarquía que iba desde el cerebro y los músculos- la Nobleza- hasta "aquellos órganos y vasos no tan realzados y proficuos ni exquisitos", es decir la plebe (José de Santiago Concha, 1762) ${ }^{20}$.

Los modernistas ien el siglo XVIII y los liberales en el XIX, que satirizaban las manías nobiliarias, que exaltaban al intelectual; - aquellos que confesaban súposición delclasesmedia (Rossi, quizás Unanue) o describían esa clase con cierta simpatía (Ignacio de Castro, 1782) sostenían al mismo tiempo la necesidad teórica de las jerarquías sociales en general; y en lo práctico una reforma moderada, casi nula ${ }^{21}$. Cuando nosotros leemos en los textus de esa época "igualdad" quiere decir, o igualdad ante la Ley o igualdad ante Dios; pero en ningún caso, liberales, católicos o ilustrados, trasfirieron esa igualdad jurídica y religiosa al plano económico-social. No incluiré aquí los ejemplos que pueden encontrarse en mi estudio sobre las ideologías políticas del siglo XVIII. Escogeré algunos pocos: Unanue (El Verdadero Peruano, 1812) para quien de no existir gradaciones y desatados los lazos de la subordinación, la sociedad caería en una anarquía homicida. El Manual del Republicano -(leído en Lima por la misma época) a su vez limitaba la igualdad a la igualdad ante la Ley y al goce de unas pocas y abstractas cualidades racionales; y Baquíjano, el tan famoso precursor, quien dijo en su Elogio al Virrey Jáuregui (1781) - como se lo reprochó el rioplatense Maziel -que la Naturaleza no se aplic xba por igual en la formación de cada ser hu- 
mano: al villano lo producía sin esfuerzo - cito al pié de la letray le olorgaba una "virtud mediocre", buenc: para la obediencia; mientras que se revestía de brío y de esmero para hacer nacer a los h:jos de nobles familias " 2 . Recuérciese en fin, que para insultar a los españoles de la plebe, el criollo Riva Ágüero no encontró en sus 28 Causas peor ccrlificativo que el de "bozc'es" por semejanza despreciativa con los negros (negros que más tarde aplaudieron a Riva Ágüero por las calles de Lima al grito de "Viva el Niño José"); del mismo modo que el Marqués de So:o Florido se había burlado años antes de los palanganas (negros presuntuosos); o que en 1814, El Investigador -laicista y libertino a ratosse había indignado contra la insolencia de los descendientes de esclavos ${ }^{23}$.

2. Los anteriores análisis nos indican la riqueza y la complejidad del concepto católico de la economía y en particular de su valoración del trabajo; $y$ en consecuencia las precauciones que debemos adoptar al describirlos. En la construcción de ese concepto y de esa valoración, la Iglesia manejó elementos muy diversos que no pueden ser situados, todos ellos, en una misma categoría. Pueden distinguirse al respecto hasta tres grupos o niveles: 1) Esquemas conceptuales propiamente religiosos (aunque en su origen hubieran pertenecido a uno de los dos grupos siguientes); a esta clase pertenecían las definiciones del trabajo como castigo y virtud; ocasiones en quē la Iglesia basaba su doctrina en las tradiciones biblicas y en. Ias normas del cristianismo primitivo; 2) Esquemás de confrontación; ente" la sociedad secular y la sociedad eclesiástica; sin distinción de lugar ni tiempo. Correspondían a este tipo los esfuerzos for demostrar la utilidad social de la Religión Católica y la afirmación de que el trabajo censtituía uno de los primeros fundamentos de la economía. La Iglesia se planteaba aquí en forma general las relaciones entre la Religión y el Siglo (economía, sociedad) sin referencia explícita ni preferencia por un determinado tipo de sociedad; 3) Esquemas de compromiso; es decir concesiones o adaptaciones del pensamiento religioso en favor de un determinado tipo de sociedad, aristocrática y jerarquizada (condenación de la movilidad vertical de los grupos sociales; reenvío de las valoraciones económicas al cuadro más amplio de la realidad social, etc....).

- La enumeración de esos diversos tipos no corresponde, desde luego, a la cronología y a la importancia que tuvieron en la ideología eclestástica del siglo XVIII tal como fue formulada en el Perú. 
Es útil observar asimismo que entre esos diversos niveles o grupos conceptuales hubo una comunicación permanente; un "viaje de ideas" derivado en parte de una necesidad interna de coherencia, que no se ha de examinar ahora; y también de la índole y el contenido mismo de los conceptos empleados. Este último es el caso de la medida en que se acordaban o no las condenaciones de afán de lucro y de la movilidad social; elemento religioso y elemento de compromiso que, procediendo respectivamente de un ideal ascético cristiano muy antiguo y de un ideal aristocrático más reciente, convergían en una misma defensa de la estabilidad de las clases.

Nosotros podemos advertir así dos tendencias principales en el pensamiento de la Iglesia; tendencias que la Iglesia no resolvió ni sintetizó. Una de ellas tradicional, surgida de la moral y de la visión del mundo del cristianismo primitivo; la otra, accidental desde este primer punto de vista, y en que la Iglesia traducía los intereses concretos de una clase determinada. La doctrina económica de la Iglesia osciló entre ambas; sujeta como estaba ella misma, la Iglesia, a contradicciones internas. Pues el catolicismo se profesaba como una sociedad universal, por encima de las naciones, las razas y las clases; mientras que al mismo tiempo, desde el siglo XVI ligaba su suerte a los estados europeo modernos, a la monarquía absoluta o a regímenes parecidos (aristocráticos) y a las antiguas y nuevas clases dirigentes, sin resignarse no obs-

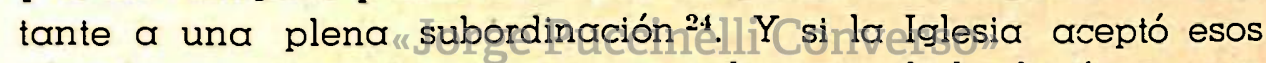
vínculos onerosos, fue, en parte y en la mejor de las hipótesis, porque paradójicamente y para el cumplimiento de su misión universal le urgió un mecanismo temporal que sólo podían suministrar los poderes civiles. Mas estos poderes civiles - y los compromisos que con ellos contrajo la Iglesia- no podían ni querían ser considerados como simples instrumentos al servicio de un ideal religioso que los excediera; ni hubiesen concedido ayuda gratuita a una Religión que combatiese los fundamentos del orden regido por esos poderes. En otras palabras, para promover lo religioso en el interior de las sociedades seculares, la Iglesia adoptó una política que entorpeció aquella promoción.

Los costos ideológicos para la Iglesia de ese proceso de secularización -en el significado más amplio del término- son particularmente claros cuando se examinan sus doctrinas económicas y sociales. Desde esta perspectivo deben ser comprendidos los 
esquemas conceptuales clasificados en las páginas precedentes. No hay que subestimar sin embargo la persistencia de las ideas tradicionales y de las pretensiones de universalidad y autonomía de la Iglesia. Por muchas concesiones que hiciera el catolicismo -y fueron gravísimas - subsistieron siempre ciertos criterios básicos; a través de ellos la Iglesia reinvocaba su primacía sobre el mundo profano. A unos y a otros, humildes y poderosos, la Iglesia recordaba que la norma religiosa constituía en última instancia la única regla cierta de conducta; y que por tanto era condenable toda actividad (comercio, trabajo, afán de gloria o distracción, etc....) desde el momento que se pretendiera convertirla en el sentido o en el móvil exclusivo de la existencia.

b) La riqueza.- 1. Lo dicho acerca del trabajo y de la actividad económica en general es válido también, como se verá en este capítulo, a propósito de oiros fenómenos sociales, tal como fueron vistos y juzgados por la Religión Católica durante el siglo XVIII. Examinaremos primero las imágenes del pobre y del rico, como símbolos religiosos y económicos a la vez, a fin de comprender después lo que significaban la caridad y la ayuda al prójimo en el pensamiento de la lglesia.

Señalemos desde ahora que la riqueza despertaba la desconfianza de los autores eclesiásticos; y que de otra parte, la diferencia entre el ricQ Ỷoeli pobrecaparecía como yna situación normal

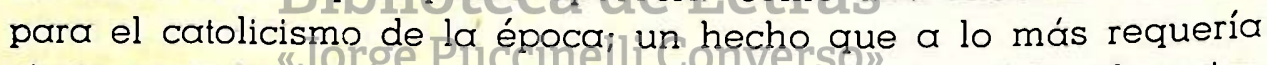
cierto control o una cierta reglamentación. Contra el hombre rico había un prejuicio cristiano muy antiguo que fue recogido por los textos eclesiásticos del siglo XVIII. La riqueza por sí mismo era un don de Dios, pero era necesario saber en qué condiciones había sido adquirida y usada.

"Las riquezas son según su naturaleza un bien inocente y procurarlas con moderación no hace al hombre criminal. Son como dice el Espíritu Santo un don de su mano liberal y solicitarlas para los fines que las concede lexos de repreenderse como un vicio podría exponerse al exemplo como virtud... No es pues la posesión sino el mal uso de ellas el que conduce a su perdición. Con todo si tienen estas ventajas también tienen sus peligros: si alguna vez redimen de los pecados y promueven la virtud; más comunmente resfrían la piedad y facilitan la culpa" 25 . 
De ahí, según un impreso limeño de 1745, que si ante los tribunales humanos era suficiente probar la falta de usurpación de los bienes, el cumplimiento de ciertas formas; Dios en cambio exigía además, para legitimar la propiedad, el título supletorio del uso cristiano que de ella se hubiera hecho ${ }^{26}$. "Las riquezas no pertenecen a los ricos, que son unos puros ecónomos de los bienes que la Providencia les ha confiado en depósitos: tienen la obligación de emplearlos a ventaja del que les confió su cuidado" "2т.

Las riquezas no podían estar sometidas a las reglas laicas del provecho personal. No se trataba de engrandecer a un país o a ciertos particulares por el aumento material de sus bienes sino de conciliar ese aumento con el espíritu cristiano. La riqueza conseguida por codicia, por afán de lucro, era una "mala riqueza", una "riqueza mal habida". En primer lugar por sus procedimientos, por el dolor que había costado al pobre. En el origen de muchas de esas fortunas se encontraba "el sudor que el pobre vierte en busca de su pan", la astucia y la ambición de los que descarnaban al pobre 2s. Esos hombres, esos ricos sin conciencia decía el padre Gonzales Laguna, de quien cito las frases anteriores, más que cristianos merecían el nombre de serpientes voraces, pues no reconocían otra ley que sus apetitos.

"La felicidad de un reyno más que en la opulencia y nativa riqueza, estriba enetener hombres on quienes resplandezca el amor a la patria, la sobriejad, candor, desinterés, providad, espiritu, poder, geiferosidad, conque difundirse en favor, de sus semejantes. Hombres que si emprenden las laboriosas fatigas a que fué condenada la descendencia de Adán, no sea para refrigerarse en ellas con el sudor que el pobre vierte en busca de su pan, sino partiendo el suyo con él, y extendiendo la felicidad si fuera posible sobre toda la tierra. Mas $j O$ h, que extraño fenómeno es un hombre de esta especie en nuesira época! : En ella no se vé más que inercia, sórdida ambición, tiranía paliada, naturales partos del bárbaro Egoismo. Hombres que o son por su inacción el oprobio de su naturaleza racional, o por su criminal industria afrenta de la religión, no destinando sus manos ni su ingenio a más que a descarnar astutamente al pobre y nutrirse de su macilenta sustancia impunemente: condición propia de los grandes peces y de las serpientes voraces, que nada perdonan en la mar y en la selva, no reconociendo poder que los reprima" ${ }^{29}$. 
Contra ese mal rico que explotaba a los miserables se pronunciaron también los arzobispos Liñán y Berroeta $(1695,1756)$. Para ambos, los terremotos que habían asolado a Lima eran un justo castigo de las faltas de sus habitantes. Liñán y Cisneros mencionaba entre las peores el comportamiento tiránico de los amos para con sus esclavos y criados. Los señores, decía el arzobispo, los ricos, los poderosos, debían ser verdaderos padres de familia, imágenes de Dios y del Rey: debían conceder días de descanso a sus servidores, no encargarles tareas superiores a las fuerzas humanas y tratarlos siempre como hermanos redimidos por la sangre de Cristo. El tiempo y el dinero que perdieran los ricos al cumplir esas normas, les serían devueltos con creces por Dios mismo ${ }^{30}$. Berroeta participaba de estas ideas. Los que defraudaban a sus jornaleros, los expoliadores de viudas y pupilos, etc... venían a ser, según él, los verdaderos responsables de las calamidades públicas, "porque sús clamores (del pobre) si no son escuchados por los hombres, por desvalidos, llegan a los oídos de Dios" ${ }^{31}$.

2. Pero además de pecar contra la caridad y el amor al prójimo, el rico codicioso cometía un segundo pecado, más grave, un pecado de profanación que explicaba y comprendía al primero. En otras palabras, el catolicismo discernía y reprobaba en aquella codicia una visión utilitaria del mundo, la hipertrofia y desviación de la actividad éconómica. Dios había creado el universo para que los hombres gozasen de sus maravilas. "Todo este mundo - decía el arzobispo Liñán y Cisneros- es un grande libro escrito con su Dedo divino y todas las creaturas son las letras de él". El hombre que viera en esa creación nada más que una oportunidad de enriquecimiento, el rico que saliendo al campo no supiera del trigo sino su precio en el mercado, tantos otros que en su sed de dinero se negaban a contemplar las magnificencias de la tierra, todos ellos, pecaban contra la belleza del mundo y contra el generoso amor de Dios. El arzobispo que proponía estos temas a la meditación de los poderosos, añadía: "Y cuando salieron al campo a la vista de su labranza, los dueños de ella no se ocupen sólo en atenderla, sino mediten también la amenidad del lugar, lo verde de las yerbas, la hermosura de los cielos, la libertad natural de que gozan, pudiendo haver caído en la inferior condición de sus criados y esclavos que miran trabajando, logrando la ocasión que les ofrece todo lo referido para levantar su espíritu a Dios Nuestro Señor" 82 . 
[La reiteración de estos ideales a través del siglo XVIII nos obliga a preguntarnos si a ese propósito la Iglesia se refería a la situación económica concreta del Perú; o si al contrario se contentaba con repelir su doctrina tradicional. ¿La miseria de los pobres, el afán de lucro, la codicia, fueron o no simples figuras retóricas? Más precisamente den quiénes pensaba la Iglesia cuando exponía su doctrina conira el Mal Rico y contra la visión utilitaria del mundo? Recurrir en todos esos casos a la fórmula "clases dirigentes", nos induciría a un error; ya que habríamos identificado de antemano clases dirigentes y riqueza sin tomar en cuenta los diversos tipos de rico y de riqueza que hubo en el Perú colonial; y $\sin$ examinar tampoco las tensiones que desde el sigio XVI hasta la Emancipación caractorizaron a los grupos privilegiados.

A primera vista el utilitarismo dominabe por igual al hacendado que al minero o comerciante; y sería imposible establecer otras correlaciones sociales más nítidas. Esa conclusión es exacta, en ler medida que toda aciividad económica supone el utilitarismo o afán de lucro. Más, lo que interesa scber, y lo que en particular preocupaba al catolícismo del siglo XVIII, es un delerminado grado, la forma más extrema y viciosa de ese utilitarismo; el momento en que como denunciaban Gonzales Laguna y Ladrón de Guevara, el hombre no reconocía otro deseo y ley que la ganancia Y se hallaba por consiguiente incapacitado para gozar de cualquier belleza y de cualquier forma de vida espiritual cristicna.

Comencemos por ensayar una clasificación de las psicologías y actitudes de algunos grupos sociales en función del lipo de riqueza que poseían. Al respecto no es nosible hablar de una nobleza terrateniente By de una burgussia cemered. Las líneas de división entre una y oira fueron nuy débiles en el Ferú. En primer lugar porque "parte de lechobleza se ladshaba al comercio; y después porque los comerciantes enriquecidos accedían a la nobleza mediante la compra de títulos o/y por lo que Pezet llamó en 1812 "los enlaces desiguales" con la antigua aristocracia ${ }^{33}$. Este fenómeno de mutua aproximación se inició desde la Conquista que fué tanto una empresa guerrera y misional como una empresa económica ${ }^{34}$. El Inca Garcilaso hablaba de escs mercaderes-soldados, quizás amigos de su padre, que conducían sus carges de coca por el camino de la sierra, seguidos de sus ojeadores y perros de caza; "era consentidlo, decía en otro pessaje, a cualquiera, por noble que fuese, de tratar y conirciar en favor de la propia hacienda". En el caso particular de Lima los testimonios abundan acerca de esc simbiosis y confusión entre comercia, nobleza, bu:guesía. Véanse por ejemplo para el siglo XVII las páginas del Judío Portugués y el divertido horóscopo del cronista cqustino Calancha ${ }^{3 i}$.

Este proceso se intensificó desde fines del siglo XVII y hasta la segunda mitad del XVIII debido al "empobrecimiento de la nobleza" ciel cual hablaron con amargura Bravo de Lagunas y Victo- 
rino Montero ${ }^{3 a}$. El noble que no se dedicara al comercio - o a la burocracia bien remunerada -o que no aceptase el parentesco con los nuevos ricos, estaba condenado a la miseria y prácticamente a la pérdida de su rango. Anotemos de paso que ese empobrecimiento condicionó también el celibatismo, las falsas vocaciones religiosas y la proliferación de los amancebados que huían de las responsabilidades económicas del matrimonio. A estos recursos, simples paliativos de la pobreza nobiliaria, se refirieron, condenándolos, algunos particulares (Feijóo de Sosa, Bauzate, Pezet), el Estado y la Iglesia ${ }^{37}$.

A finales del siglo XVIII los más ilusires linajes, o los más poderosos, confesaban algún ascendiente, con frecuencia el fundador, que había poseída una hidalguía mediana o dudosa y a quien la fortuna le había permitido ascender hasta la primera aristocracia. El primer Conde de Vista Florida, por ejemplo, el español Baquíjano, había sido un simple hidalgo montañés antes de comprar su título a la Corona y de emparentar con el linaje ya criollo de los Carrillo de Córdova. Aquellos mismos como Bravo de Lagunas y Victorino Montero, que protestaron contra esa desintegración de la nobleza, no escaparon de una u otra forma a las tendencias generales. Un lejano pariente colateral de Bravo de Lagunas llegó con el tiempo, hacia 1807, a dedicarse al tráfico de esclavos ${ }^{38}$. En cuanto a Victorino Montero, los hechos son más ilustrativos. Este aristócrata orgulloso no vaciló como corregidor en comerciar (a pesar de que reprobaba teóricamente el comercio de los corregidores) y con el auxilio de sus parientes monopolizó el comercio norteño de la cascarrilla y las breas ${ }^{39}$.

Fué precisamentelentos grupos que ascendían a los primeros planos sociales y en la nobleza que quería mantener sus posiciones, donde se pudo observar el tipo de utilitarismo condenado por la Iglesia durante el siglo XVIII. No sin resistencias, además de la Iglesia, por parte de aquellos sectores recalcitrantes de la nobleza que no pudieron adaptarse. De esos últimos sectores y como una expresión clarísima de resentimiento, surgieron los ataques contra el afán de lucro y por extensión contra toda forma de enriquecimiento realizada al margen de los cuadros y reglas tradicionales. Particularmente contra el comercio considerado por ellos como la negación de todo ideal aristocrático. Nosotros poseemos pocos testimonios directos de esa reacción si exceptuamos los ya citados de Bravo de Lagunas y de Victorino Montero. Pero en cambio son innumerables las réplicas escritas por los que de una u otra manera se sentían lesionados en sus intereses por aquel desprecio. En defensa del comerciante fué que se pronunció el modernismo peruano de fines del siglo XVIII (La Sociedad Amantes del Perú) señalando ya fuera las virtudes y utilidades del comercio o burlándose de la ociosidad de los mayorazgos. Diez años antes el español Carrió de la Bandera había dicho en su inédita Descripción del Perú (1782): "El mostrador de un comer- 
ciante es el taller donde se fabrica la prudencia, la templanza, el agrado con buenos y malos y la paciencia con todos" 40 y había añadido - ¿aludiendo a la tesis contraria de Montero?- que el comercio era un buen preparativo para la magistratura. La persistencia del prejuicio aristocrático, a pesar de esas defensas, puede apreciarse por el hecho de que algunos comerciantes de la nobleza creyeron necesario justificarse de sus actividades, como lo hizo don Juan José Avellafuerte en una carta privada que no destinó a la publicación ${ }^{41}$. Todavía en 1801 el criollo Arriz parece haber tenido presente ese desprecio nobiliario por el mercader cuando elogió a los comerciantes en el mismo momento que España nombraba Virrey al irlandés O'Higgins, de quien se decía en Lima que había sido vendedor de baratijas en su juventud $\mathbf{4 2}^{2}$.

En estas circunstancias la Iglesia adoptó una doble política. Contra el resentimiento de los hidalgos empobrecidos que despreciaban al nuevo rico, afirmaba con San Pablo y Feyjóo "que los ricos por ricos son de alguna manera acreedores al respeto que se les atribuye" puesto que su prosperidad había sido concedida por Dios ${ }^{43}$; pero al mismo tiempo advertía (Lima, 1745) que las riquezas no debían trasformarse en un medio ilegítimo de ascenso social ni servir a la emulación entre las clases ni a una magnificencia desproporcionada con al nacimiento ${ }^{44}$. De otra parte, no he encontrado ningún elogio oficial del comercio en los textos eclesiásticos, fuera de alguna que otra recomendación tibia e indirecta $\mathrm{y}$ de dos pasajes escritos respectivamente en 1792 y 1812 por el franciscano Olavarría y por el clérigo limeño Larriva, hijo de comerciantes y clérigo apesar suyo. ${ }^{45}$. Abundan en cambio, como veremos en otro lugar las condengciones contra logusura y el monopolio, prácticas muy comunes entre los comerciantes coloniales y cierto énfasis en lá prohibiciónc del comerdio a 90 's sacerdotes, que demuestran que las simpatías de la Iglesia hacia el comercio en general fueron entonces muy débiles. Por cierto que habría que considerar aquí algunas actitudes de transición. No podemos olvidar por ejemplo que si Gonzales Lagunas condenó el utilitarismo lo hizo en un artículo entusiasta en favor del español Bezares cuyos proyectos de colonización en Huamalíes representaron un paso de la colonización heroica y guerrera a la gran explotación colonial de tipo capitalista ${ }^{46}$.

\section{c) el pobre; la caridad}

1. La riqueza evocaba de inmediato su imagen opuesta y complementaria, el semblante de los pobres. El pobre y el rico se hallaban indisolublemente unidos; cada uno de ellos condicionaba las obligaciones y la existencia del otro. El vínculo entre ambos, según la Iglesia, no debía ser el de la explotación, el desprecio o 
la indiferencia, ni siquiera el de la justicia social laica, sino el superior y sagrado de la caridad. Caridad cristiana, como decía el Mercurio Peruano y no filantropía filosúlica dictada por escrúpulos humanitarios "i.

¿Quién era el pobre, qué simbolizaba para el cristianismo? La Iglesia reivindicaba para el pobre la veneración debida a Cristo. Los pobres, decía el dominico Osorio, son los elegidos del Señor, su imagen en la tierra; y era deber de todos los cristianos y en especial de los cristianos poderosos y ricos, disminuir las miserias de estos hermanos suyos. "Porque levantar al pobre de la tierra... y del asqueroso estiércol de su desprecio es propio de la deidad" 48 . Dios había concedido fuerza y abundancia a los ricos para que éstos se inclinaron hacia los que gemían; para que a manera de los Cedros de Líbano dieran, según el consejo de San Agustín, sombra a los desamparados. Los sufrimientos del pobre se asimilaban a los de Dics Encarnado. Dios estaba presente, a la vez, en las majestad suntuosa del emplo y en la miseria de los hospitales. El Dios verdadero, nacido humildemente en la tierra, era el Dios-Monarca y también el Dios-Mendigo que rogaba una limosna. El jesuita Sánchez, de cuyo farnoso sermón de San Lázaro son las frases copiadas, agregaba que el pobie poseía un título supremo para demandar el auxilio de lus ricos. su necesidad; no necesitaba de otros: "y así todo lo que se aurnenta esta necesidad deba crecer también este derecho" "4.

La riquez sin caridad, ef rico indiferente constituían para la Iglesia un contrasentido moral. Sin la caridad ninguna relación humana, y menos que otras, la económica, era posible. La caridad, según José Manuel Bermúdez era la primera de las virtudes y una de las formas principales de la gracia. De ella procedían todos los bienes del alma pues nada había en ella que fuese envidia, jactancia o ambición 50 . "Es un principio asentado en la sublime teología de San Pablo que la caridad es la forma, el alma, el cerebro y corona de todas las virtudes". O, minúscula variación de Marimón, si todas las viriudes son el cuerpo de nuestro espíritu, la caridad es el alma del espíritu ". Sin ella todas las acciones cristianas se desvanecían como sombras confusas.

Es necesario precisar este concepto cristiano de la caridad y diferenciarlo, como se hizo entonces, de la ayuda al pobre basada en reflexiones morales, políticas o filosóficas. La obligación del rico para con el pobre no era un dictado de la Razón sino 
una promoción del afecto, una disposición interior del alma cristiana, el verdadero amor al prójimo y al hombre, según la definía el arzobispo del Corro en 1759 j2. Sin esa disposición interior toda obra era nula e ingrata a los ojos de Dios ${ }^{63}$. De otra parte la caridad no consistía en el exceso de limosnas ni en la pura distribución de riquezas. No era magnificencia porque la magnificencia, como hemos visto, podía servir a la emulación entre las clases; ni generosidad aristocrática, dispendio o compasión indiscreta. La caridad empleada por esos motivos o en obras que realzaban el prestigio del donante más de lo que aliviaban al pobre, no era un acto de caridad cristiana. Dios pedía humildad de ánimo al rico y nunca había ordenado que se le construyeran frágiles palacios sino que al contrario, pedía que, por amor y deber, se le levantaran y sostuvieran esos Templos Vivos que son los hombres en miseria:

"No se trata de construir un templo de oración donde de baxe el Señor cubierto de una oscura nube; sino de levantar, de sostener, de conservar templos vivos dignos de su Magestad, donde habite el Espíritu en verdad y justicia. No se trata de preparar al Dios del Cielo, habitación frágil, que consume el tiempo, que roe la polilla y reduce a cenizas el fuego; sino de unas habitaciones y moradas incorruptibles, en que la sabiduría tiene sus delicias y habita eternamente' ${ }^{54}$.

A estas delimitaciones de lo que se entendía por caridad se agregaba otra mucho más importante en la práctica. La ayuda al prójimo no debía ser limitada y sin restricciones, pues si el rico se hallaba en la obligación de socorrer a los pobres, también era de mandato divino que todos los hombres trabajasen. Ambas normas, Caridad y Trabajo, debían aplicarse conjuntamente, respetando el orden providencial del universo. Aplicarlas "razonablemente", es decir cuidando de no proteger la pereza ni de ahuyentar de sus ocupaciones al pueblo. El cristiano, señalaba una traducción limeña de Muratori, había de "evitar con su liberalidad de hacer perezoso y aborrecedor de la fatiga al Bajo Pueblo" 55. En la pobreza era necesario distinguir la falsa de la verdadera y disciplinar la caridad para hacerla compatible con las exigencias religiosas y sociales. El cristianismo no venía a turbar la organización civil sino a mejorarla. En el Universo todo es orden, todo 
se halla sometido a reglas, hasta las virtudes y entre ellas la caridad.

"El orden es el que da perfección a todas las cosas. Quando el Espíritu Santo nos quiso hacer comprender que Dios obraba comó Dios nos dixo que todo lo hacía con orden. La misma Charidad Reyna de todas las virtudes (dice Santo Tomás) dexaría de ser virtud si le faltase el orden..." "מB.

Las mismas ideas encontramos en el Mercurio Peruano y en los escritores laicos del siglo XVIII. El proyecto de Ladrón de Guevara para la construcción de un hospicio de pobres, el discurso de Lequanda sobre la vagancia, etc insistían en que la caridad debía ser compatible con el trabajo y no proteger al ocioso ${ }^{55 a}$.

[No es posible, en consecuencia, responsabilizar al calolicismo y a la caridad cristiana de la abundancia de mendigos durante el siglo XVIII. Diversos documentos y fuentes impresas prueban que ese fenómeno fué el resultado inevitable de otras causas de tipo económico y social, al margen de las doctrinas eclesiásticas. La mendicidad fué una respuesta a la subocupación o desocupación crónica, a la falta de oportunidades de trabajo que caracterizó a nuestra economía desde fines del siglo XVII. Algunos autores coloniales prefirieron sostener que el factor decisivo de la pobreza del pueblo era su "falta de amor al trabajo"; y el propio general Mendiburu, a médiddos del sigloseXIX se inclinaba por esta hipótesis, sin explicarse nunca el porqué de esta inclinación supuestamente natural ar for perezan, nil a que grupos sociales debía restringirse en todo caso parcialmente esa explicación. Porque en vez del mendigo y del pobre debemos hablar de los mendigos y de los pobres y de sus muy diferentes y hasta opuestas categorías. La teoría de la "falta de amor al trabajo" conviene en cierta medida a la plebe criolla, española $y$, en menor grado, a la plebe mestiza de la ciudad. En ellos los prejuicios del honor nobiliario, que no merecían por nacimiento, les impulsaba a rehusar cualquier ocupación indigna. A ellos se refirió Ladrón de Guevara cuando dijo que muchos preferían pedir limosna a trabajar. "Teniendo por más vil la condición de fámulos que la de pobres" ${ }^{57}$.

O Unanue que lamentaba que las mujeres criollas y de la plebe no quisieran dedicarse a la obstetricia por considerarlo un oficio vil $\mathbf{6 8}$.

En Pereyra y su descripción de Arequipa, en el ya mencionado Lequanda, en los viajeros extranjeros del siglo XIX pueden leerse pasajes que confirman esta interpretación. Bastaría además recorrer las solicitudes de limosna presentadas a los obispados. .He recogido, por ejemplo, algunas correspondientes a la diócesis 
serrana de Huamanga. Lo primero que llama la atención es como algunos de los peticionarios invocan su antigua situación social y piden ayuda "conveniente a nuestro estado y calidad"; se nombran como "pobres vergonzantes" (que se averguenzan de pedir limosna) y estiman con frecuencia tan importante como el vestido y la comida, una dotación para que sus hijas entren o permanezcan en los conventos de clausura o para que el hijo siga estudios en el seminario eclesiástico y tome las órdenes sagradas. Mientras que es evidente que otros han escrito o hecho escribir sus rogativas desoués de haber buscado inútilmente un empleo y no preienden sino lo indispensable para seguir viviendo 59.

Fué ese último grupo de pobres y mendigos, que buscaba trabajo y no lo obtenía, el más numeroso en las ciudades virreinales. En Lima y en los demás centros costeños un porcentaje de ellos estuvo formado por los esclavos viejos, enfermos o inválidos a quienes sus amos daban libertad cuando ya les eran inútiles "y después de haver servido o dado jornal lo más de su vida, los abandonan a la Tropa de los Mendigantes, relevándose a costa del común de la obligación de sustentarlos" " tingente estuvo suministrado por la migración campesina hacia las ciudades, de la cual nos inabla entre otros Carrió de la Bandera. Por él sabemos que había muchos "chinos vagos" en Arequipa, Huamanga, Cuzco y Huancavelica y que las provincias se despoblaban. Bajan las serranas, decía el despreciativo Carrió, con su pelo y su lana, ofreciéndose de sirvientes. Escogían de preferencia las casar que les permitieran salir a la calle para crearse una ilusión de libertád. f"Queriendo más servir a un pobre por el simple cubierto... que en la casa más opulenta con clausu$\mathrm{ra}^{\prime \prime}{ }^{11}$. Muchas veces sinembargo ho lesi érásposible ni siquiera aspirar a estos puestos domésticos, por la gran demanda que había de ellos. La situación era todavía más aguda en las ciudades costeñas y en la capital, donde el número de sirvientes era ya elevadísimo. Así a fines del XVIII, el censo de Gil de Taboada contó, para sólo Lima, y sin incluir los esclavos, 2,903 sirvientes de castas y 474 de raza blanca, sobre una población que apenas sobrepasaba los $50 \mathrm{mil}$ habitantes. A falta de la servidumbre, el inmigrante campesino como el hombre de la plebe, que había nacido y residía desde hacia largo tiempo en la ciudad, no encontraba otras ocupaciones. El inmigrante por su falta de adaptación; y ambos, además, porque los oficios 0 artes mecánicos y viles estaban muy poco desarrollados y se mantenían gracias a una dotación mínima de trabajadores.

En lugar de la falta de amor al trabajo, se debió pensar enionces $\in n$ reformar las condiciones generales del trabajo. Más los proyectos sugeridos al respecto (Ladrón de Guevara, Lequanda) tropezaron con las estructuras rígidas que encontraba natural por ejemplo que Lima, sobre los 50,000 habitantes mencionados, tuvie- 
ra 4,831 religiosos, 9,229 esclaros; mientras que sólo existía 1,155 artesanos, labradores, jornaleros y otros parecidos.

Así pues ni la caridad "racionalizada", ni la reforma de los días festivos podían realmente modificar esta pretendida ociosidad de la plebe ni corregir la taita de amor al ircibajo de algunos sectores de ella. La Iglesia y el modernismo que a partir de estas reflexiones económicas extendían su indignación a otros fenómenos patológicos (prostitución, amancebamiento, homosexualidad, sífilis, abortos, abandono de los niños, etc....) no plantearon el problema con la misma lucidez que supieron emplear en otras materias menos peligrosas. Sacerdotes y laicos escribían fácilmente y agotaban la argumentación cuando se trataba de combatir a los escolásticos y al barroco, a los galicismos de la oratoria - de discriminar el verdadero significado de un pasaje oscuro de los padres de la Iglesia y de las leyes del reino; más en otro terreno, en el social y económico, sus críticas esporádicas y truncas, dejan sospechar su complicidad quizás involuntaria con un estado de cosas que se reprobaba a lo más teóricamente y con generalizaciones. Que no se diga para disculpar estos vacíos que nuesira cultura, nuestra literatura y nuestras ideologías fueron únicamenie "imitaciones" y plagios de modelos extranjeros, por que aún en ese caso habría que recordar que la imitación supone una cierta correspondencia y similitud entre el imilador y el imitado; y que este último, a través de procesos de elaboración, de selección y de síntesis, revela su propia personalidad].

2. Imitada o no, la doctrina católica de la caridad ofrecía al poderoso eBbenefico subsidiario de lajilusión de una buena conciencia. Le estaba prohibido a ese poderoso comportarse utilitariamente, debía verse a sí mismo como un ecónomo de los bienes de Dios, y mirar al pobre como a un hermano, imagen del Cristo Doliente. Cumpliendo esas taxativas y en especial los deberes de la caridad, el rico convalidaba sus derechos a la riqueza. $\mathrm{El}$ orden económico puramente profano se reintegraba al sobrenatural. Las desigualdades sociales que no debían ser quebrantadas por el trabajo y ni siquiera en favor del rico, recibían otra vez, $y$ en sus puntos críticos más extremos (Rico-Pobre) la autorización plena de la Iglesia. De un lado el Bajo Pueblo trabajando exclusivamente para el sustento; del otro los ricos y sus diversas clases de privilegiados. Entre ambos la caridad como un medio compensatorio y regulador. El catolicismo quería con esta ideología evitar los excesos del rico (la explotación inhumana, el lucro) y los excesos del pobre (la ociosidad; la rebelión), optando por el compromiso, la conciliación aparente de opuestos. En la alternativa de escoger, radicalmente entre Dios y el Mundo, la Iglesia 
acluó como los modernistas peruanos del XVIII que a una coyuntura semejante (escoger entre la religión tradicional y el pensamiento moderno) decidieron construir un sistema ecléctico que les permitiera no definirse.

\section{d) la usura y el monopolio.}

1. Si la riqueza pudo ser aceptada, después de todo, por la ideología católica; la Iglesia en cambio no transigió en las formas más viciosas de este espíritu utilitario de empresa que hemos visto anatemizar por Gonzales Laguna y Liñán y Cisneros. Dijimos al comentarlos en un paréntesis anterior que esas reprobaciones tocaban de cerca, entre otros, a los comerciantes criollos y españoles que se dedicaban a las prácticas de la usura y del monopolio. Acerca de este tipo de comerciantes y de su influencia nociva en la vida colonial, existía un acuerdo unánime, Ningún autor del siglo XVIII los defendió. Contra los monopolistas del trigo se pronunció el Oidor Bravo de Lagunas; contra los acaparadores de víveres el abogado Borda y Orozco en 1768; contra las pretensiones de los asentistas de las breas, Feyjóo de Sosa en 1791; y contra los usureros, la carestía del dinero y los altos porcentajes de intereses, Baquíjano en el Mercurio Peruano 62.

Pero la posición de ta Iglesia frente a la usura y el monopolio no debe ser inmediatamente referida l-apesar de "sus semejanzasa esas críticas laicas ni ser juzgada como la intérprete del Estado - de un grupo social para el que la libertad de comercio y las leyes naturales de la economía, entorpecidas por la usura y el monopolio, constituían la garantía de su propio desarrollo.

Sus orígenes son mucho más antiguos y se encontraban más cerca de la generosidad aristocrática y del desprendimiento evangélico que del liberalismo económico de los modernistas o que del paternalismo del Estado español. Le Bras ha indicado los textos cristianos que desde los primeros siglos precisaron la naturaleza del delito de usura. Las palabras del Nuevo Testamento ("Prestad sin nada esperar en retorno") fueron glosadas numerosas veces e incluídas en las decisiones de los más tempranos concilios (los de Elvira y Nicea en el siglo IV), en los manuales de confesores $\mathrm{y}$ en los actos pontificales (Alejandro III, Urbano III, Inocencio III, Gregorio IX) ${ }^{88}$. 
2. Sobre esta tradición primitiva desenvuelta en la Edad Media apoyaron sus decisiones los prelados peruanos del siglo XVIII. Examinemos entre otros, dos testimonios de índole diversa: 1) La Carta Pastoral escrita por Ladrón de Guevara como Obispo de Panamá, pero reimpresa en Lima en 1712; y 2) la edición limeña del Prontuario Moral de Larraga. Para el arzobispo Ladrón de Guevara el mutuo y todo préstamo a interés merecía el nombre de usura. La misma etimología indicaba la vileza de esas actividades. El mutuo castellano o Fenus latino era el Fetis griego (cría o parto) y el Morssus hebreo, cuya traducción más aproximada era mordedura; mordedura que Ladrón de Guevara, de acuerdo con San Juan Cristóstomo, comparaba a las mordeduras de las serpientes, "a la del aspid que primero causa deleite y después muerte" 61. La usura era un delito y un pecado que ninguna sociedad ni religión había tolerado; todos los derechos, el civil, el natural, como el divino, la prohibian. Qué razón, qué lógica hay, preguntaba el arzobispo, para que aquel que da Cien reciba Doscientos o trecientos. "Ciento no tiene nunca más valor que ciento" simplificaba. En el mutuo el dominio y el uso no se distinguían, como en el comodato, de modo que quien se reintegraba una cantidad superior a la que entregaba, no actuaba lícitamente.

Ladrón de Guevara admitía la ganancia del mutuo en caso de daño emergente $Y$ de-lucro cesanTe; pero con tales limitaciones que la hacian improbable. Asimismo, temiendo que los pactos con condición "expresa de restituir el daño, Ocultaran Usuras Paliadas, aconsejaba en el mismo texto someterse al criterio del con. fesor.

En cuanto a Larraga, su Prontuario reimpreso en Lima (1720) contenía varios capítulos sobre las actividades económicas recogiendo opiniones de otros autores con un juicio algunas veces indulgente $\mathrm{y}$ otras riguroso ${ }^{65}$. Su influencia fue intensa pero muy corta, pues a raíz de las disputas sobre el probalilismo se le quiso asimilar a los laxistas o teólogos complacientes. La edición que cito es anterior a su expurgación por el Santo Oticio español: Los tratados que nos interesan son en especial los tratados XLII a XLVI en los que Larraga compendió la doctrina comúnmente aceptada sobre la usura, el monopolio, el precio de mercado, los contratos, etc... Larraga demostró cierta indulgencia por los hurtos pequeños y por los cometidos sin deliberación, pero fue muy severo con aquel que cometía fraude en agravio de mu- 
chos y de la República (venta fraudulenta al por menor); exigiendo en esos y otros casos la restitución completa a fin de satisfacer la justicia conmutativa.

Examinando a continuación los contratos nominados, y en especial la compraventa, Larraga analizó otros manejos delictuosos que sin ser usura ni monopolio, implicaban también una especulación ilícita. En realidad el comerciante no debía darse por satisfecho simplemente por no haber aceptado las mercancías o por no haber prestado a interés. Pues con frecuencia se prefería un método menos visible e igualmente perjudicial: el de la especulación con los precios. Las cosas, decía Laraga, tienen dos precios, el precio legal y el precio vulgar. El primero era impuesto por el Príncipe o la República; el otro dependía de las fluctuaciones del mercado. Este segundo precio de plaza, precio de arbitrio. admitía tres gradaciones: ínfimo, medio y supremo. Para la teología moral pecaba tanto aquel que compraba por debajo del precio ínfimo como aquel que vendía por encima del precio supremo. Se exceptuaban de estas reglas, las llamadas "cosas extraordinarias" o superfluas que no fueran indispensables para el bien de la república y cuyo precio justo no era el precio medio, sino simplemente, el que fuera acordado entre las partes. Aún en esta eventualidad, como en las anteriores el vendedor se hallaba en el deber de confesar los vicios ocultos sustanciales de su mercancía, aunque no los manifiestos y taccidentales.

En lo que se refería al monopolio Larraga lo admitía simplemente en beneficio del Príncipe y de la República, el monopolio público, pero no el "monopolio por malicia" de los particulares, definido por él como la compra en abundancia a precio ínfimo para vender más tarde al precio supremo. Por último, y como Ladrón de Guevara, el Prontuario, admitía la restitución por lucro cesante $\mathrm{y}$ daño emergente, pero negaba la licitud y moralidad de toda otra forma de ganancia en el préstamo; considerando que el mutuo paliado o virtual era usura e incluyendo dentro de esta modalidad hasta la venta a plazos o crédito.

\section{La actividad económica de la Iglesia.}

En toda la primera parte de este trabajo se han empleado los conceptos de "ideología", "doctrina", "teoría económica", "imagen-valoración", "esquemas conceptuales" como equivalentes pa- 
ra designar al pensamiento económico de la Iglesia Católica en el Perú del siglo XVIII. Ese uso no puede ser justificado en esie momento. Ya en la introducción indiqué algunas de las diversas elapas a recoger en el estudio de las relaciones entre la Iglesia y la sociedad prolana. Sólo en el curso de escinvestigación, y des. pués de haberla cumplido, será posible decidir acerca del vocabulario e hipótesis iniciales. Adelantemos que ideología económica significa aquí una concepción de la reclidad económica, o de algunos de sus aspectos, que no sólo expresa e interpreta esa realidad en función y desde el punto de vista de un grupo social, sino que también aspircs con ello a justificar y a servir los intereses de ese grupo. Lo característico de esta visión ideológica es de un lado su parcialidad; y del otro, para cumplir sus designios defensivos 0 justificatorios, su pretensión de ser la única visión verdadera y valedera para todos los grupos sociales; su pretensión de negarse como ideología.

¿La doctrina social católica fue una ideología al servicio de la clase dirigente colonial; de algunos de los sectores de esa clase? Las posiciones de esa doctrina Irente al trabajo, la movilidad vertical de las clases, etc... parecen demostrarlo. Pero si la Iglesia proporcionó una justificación y una buena conciencia a ciertas situaciones sociales, queda aún por saber qué rol jugó en la construcción de esajideología la propia situación económica de la Iglesia.

Es obvio cule tesc qdrea conno un cavítulo de la historia económica de la Iglesia equivaldría a una historia económica del coloniaje. Nada conocemos aún por desgracia sobre estos temas. Nada conocemos sobre la composición de las rentas eclesiásticas en el Perú -cuantía, procedencia, métodos de reccrudación y contabilidad, inversiones, etc....- Ningún especialista se ha ocupado del diezmo, los expolios, las fundaciones pías, las cofradías, tanto las de culto como las de contribución (especies de cooperativas - sociedades mutuales de beneficencia), las tortunas conventuales, las propiedades urbanas y rurales del clero, el manejo de sus haciendas, etc... A través de esos estudios que no existen se podría reconstruir la historia del patrimonio particular de los sacerdotes seculares, del patrimonio institucional de las congregaciones y órdenes y del patrimonio público de la Iglesia; y comprender íntimamente, desde su interior, desde sus bases materiales, la historia del catolicismo en el Perú. Sabríamos entonces, por ejem- 
plo, que las oposiciones y conflictos entre el curato y la jerarquía tuvieron en parte un fundamento económico, como lo demuestran los asomos de richerismo en Polo y Figuerola (1812), las críticas de El Investigador contra la riqueza de los canónigos (1813), la comparación de los inventarios de bienes (1700-1816) y, más tarde, el solo título de un raro folleto republicano: 'Defensa de los $\mathrm{Cu}$ ras sitados por hambre" (Ayacucho, 1844) ${ }^{\circ 0}$.

Desde esa perspectiva económica el análisis del pensamiento eclesiástico recibirá el material y los giros necesarios para plantear sus propios asuntos. Entre tanto, en esta segunda parte he recogido algunas indicaciones sobre el comportamiento individual de algunos miembros de la Iglesia. Sacerdotes que se apartaron de las normas religiosas, de la propia ideoiogía católica. Sacerdotes dedicados al comercio o a la usura, contra los mandatos expresos de sus superiores. Actividades quizás delictivas que no representaron la tendencia general de la Iglesia desde el punto de vista económico, pero que nos permitirán deslindar el terreno de las futuras exploraciones.

\section{a) el sacerdote, el comercio, la usura}

1. Teóricamente el sacerdote estaba excluído de la vida económica y consagrado a los negocios espirituales del hombre. Como representante de Cristo su primer deber era la pobreza, aún en los casos que no estuviera sujet6 a ella for un voto especial. ¿Cómo podrá servir a Dios —preguntaba el capitán Fuentes en 1693el sacerdote que no se aleje de todo trato con el mundo? ${ }^{0}{ }^{\top}$. El derecho canónico y muchas reales cédulas, instrucciones y pragmáticas, inspirados en esta definición del sacerdote, habían dispuesto reiteradamente que los miembros del clero no se ocuparan en el Perú de las actividades económicas. Esas normas fueron escasamente obedecidas. Ya en el Concilio limense de 1582 hubo algunos clérigos que apelaron contra las censuras que Santo Toribio de Mogrovejo, de acuerdo con las reglas del Tridentino, hizo aprobar contra los sacerdotes dedicados al comercio ${ }^{68}$. En el siglo siguiente, a principios, el franciscano Buenaventura de Salinas incluía en su Memorial al Rey (1645?) un pasaje y unas reflexiones que demuestran cual era al respecto la conducta de los curas en la Sierra Sur del Perú. Iba Salinas en 1635 hacia el Cuzco cuando vio por las laderas de esa comarca más de 300 indios 
cargados de costales de trigo y azotados por una tropa de mestizos que les servían de guardianes. Fray Buenaventura les preguntó a dónde iban y quién les enviaba. Respondieron los cargadores que aquel trigo era del cura cie su doctrina que los remitía al Cuzco porque en su tierra lo compraba al ínfimo precio de ocho reales y otro cura en el Cuzco, amigo del primero, lo vendía a 20 y 24. Fray Buenaventura indignado predicó ésie y otros abusos, de curas y encomenderos, en el Cuzco, con grar escándalo que le provocó enemistades influyentes y fue una de las causas de su salida del Perú. En su Memorial, afeando estos tratos indignos del sacerdocio, como enemigos del Rey y de la Ley, decía que los pastores de almas son los perros fieles que guardan sus rebaños para provecho y gloria de su Dueño, sin equilinarlos y ladrando a los lobos que quieren nutrirse de la sangre de sus ovejas. El sacerdote, agregaba, no es mercader que medra con las granjerías sino Hijo de Leví, ungido del Señor, amparo y no causa de la miserix de sus hermanos.

"Los Apóstoles no consentían sino que prohibían (como auemos dicho) con seuerísimas penas, que se vendiesse la justicia ('referencia a los corregidores') y que se tratasse con la Doctrina Euangélica. Que no obligassen a Christo nuestro bien, que viniesse, y los echeassea de los Templosecomo a Ministros indignos..."

2. En la época que estudiamos desde principio del siglo XVIII hasta la Emancipación, multitud de quejas, de denuncias o de simples comprobaciones un poco desengañadas, atestiguan que la situación no había cambiado mucho desde que Salinas escribió su Memorial. La costumbre, la mala costumbre, hizo las veces de Ley; y el sacerdote, criollo, español o mestizo, se distrajo de las ocupaciones sagradas para aumentar su patrimonio particular. A ello contribuyeron las obligaciones que tenían los curas de administrar los bienes propios de la parroquia o de las fundaciones pías y la corta renta que percibían muchos de ellos como sueldo. Salvo los hijos de grandes familias con fortuna personal o para quienes el curato -casi siempre el mejor de los vacantes- significaba con frecuencia un paso a las canonjias o beneficios mayores, los demás miembros del clero procedían de familias pobres o de mediano haber y se hallaban obligados a buscar fuera de sus sueldos, el sostén diario. En otros casos, especialmente en la sie- 
rra, el cura habia contraído obligaciones delictuosas, tenía mujer e hijos y no ahorraba medio alguno para acrecer por medios ilícitos el patrimonio de una familia sacrílega.

La Iglesia comprendió durante el siglo XVIII que salvo en el último de los casos, en los demás no era posible mantener una prohibición absoluta y rigurosa. Ladrón de Guevara, lo expresó claramente en su Pastoral de 1712, cuando indicó cuáles eran las obligaciones económicas permitidas a los sacerdotes y cuáles las condenables "I. Entre las primeras, entre las ocupaciones prohibidas, Ladrón de Guevara, incluyó a todas las profesiones liberales a excepción de la medicina, para cuyo ejercicio admitió la posibilidad de una dispensa ${ }^{i 1}$. En lo que se refería a la negociación propiamente dicha, se reiteraban las normas tradicionales. El comercio era difícil de ejecutar sin culpa, pues se hallaba casi siempre animado por la codicia y porque distraía al hombre de empleos más altos y sagrados. "No es bueno para cura el clérigo que tiene negociación porque estará más en su negocio que en su oficio". Algunos pasajes de la Pastoral dejaban entender que por comercio o negociación punibles en el sacerdote, se entendía solamente la compra venta de cosas muebles con fines de lucro. Esa había sido al menos la opinión de Carlos de Graphis a quien citaba Ladrón de Guevara a través del Itinerario de Peña Montenegro. Para Graphis el sacerdote podía negociar con el ganado, pues la ganancia que obtuylesé procedía detlaherencia y no de maniobras especulatiyas. Bor esta razón porque „el aumento de bienes era un aumento natural y no debido a la industria huma. na, algunos autores habían extendido la permisión a los frutos de la tierra, admitiendo que se les guardase hasta que subieran sus precios. Ladrón de Guevara no opuso a estas opiniones otro argumento que los Concilios limenses y de acuerdo con ellos ordenó que los frutos, granos o ganado fueran negociados sólo para la conservación de frutos y sustento de la familia, siempre que fueran insuficientes para ello las rentas que el sacerdote tuviese por razón de su oficio.

3. Pocas veces la Iglesia pudo sancionar la desobediencia de esas normas como lo hizo en 1748 el obispo de Arequipa. El espíritu de lucro repudiado por la Iglesia entre los laicos constituía para ella un problema gravísimo dentro de sus propias filas. A medida que avanzaba el siglo XVIII el sacerdote se interesaba cada vez más por la vida material y las actividades económicas. Al- 
gunas veces como el obispo de Quito Pérez Calama y el redentorista González Laguna, con un espíritu "modernista" de reforma, conciliando en lo posible las reglas evangélicas con el entusiasmo de una época que había redescubierto "la utilidad social del conocimiento" y postulaba su aplicación 72. Si Pérez Calama y Gonzales Laguna se limitaron a una intervención teórica, proyectando empresas económicas de gran envergadura o protegiendo las iniciativas laicas, sin practicar ellos mismos comercio alguno, muchos otros eclesiásticos compitieron al lado de los comerciantes virreinales, en el mismo plano que ellos y con las propias reglas de juego usuales entonces. Hubo curas -Carlos García e Isidro de Aguilar (parroquias de Huayllata, 1786 y de San Juan de Oyolo, 1793) - inventores o arbitristas que propusieron al Estado español máquinas y métodos para mejorar la explotación de las minas ${ }^{73}$. Otros explotaron las minas por su cuenta; sabemos así que las de brea en Amotape y Parinacochas tuvieron por copropietarios a los curas de esos lugares. En la capital, bajo la vigilancia próxima del arzobispado, no faltó sacerdote dedicado, no ya al comercio sino a la industria, a una de las 60 calificadas pomposamente de "fábricas" por el Censo del Virrey Gil de Taboada. Los documentos mencionan por ejemplo a un presbítero Cayetano de León que nunca fue molestado por sus superiores jerárquicos y que no tuvo otras dificultades para continuar la elaboración industrial de pergaminos que las quejas decsus leolindantes ${ }^{74}$.

En sus actividades económicas el sacerdocio demostró una capacidad de organización y una ambición en nada inferiores a la de los laicos más avezados en el comercio. Proyectaron irrigaciones como el cura de Cailloma Isidro Gudiño (1800) y audaces inversiones inmobiliarias que alguna vez terminaron en el escándalo público: caso del oratoriano Amil y Feyjóo ${ }^{75}$. El más célebre de estos sacerdotes, no por razones económicas, fue el modernista Toribio Rodríguez de Mendoza de quien Rodil creía hacia 1824 que tenía 300 mil pesos de capital. Rodil exageraba, pues Rodríguez de Mendoza murió pobre ${ }^{70}$, más no porque así lo hubiera deseado. Años antes había adquirido, con auxilio de la Caja de Censos, una hacienda en Amancaes por un valor total de 90 mil pesos y a fines del siglo XVIII solicitó permiso para explotar una mina en las proximidades de Chachapoyas. Por esta vez el Fiscal opinó en contra recordándole a Rodríguez de Mendoza -tex- 
tualmente- que los deberes de su investidura eran incompatibles con este tipo de negociaciones ${ }^{i 7}$.

Es dentro de este ambiente de disolución del ascetismo cristiano entre la gente de Iglesia, que cobran verosimilitud las leyendas sobre la inmensa riqueza de los jesuitas. No fueron ellos, según se ha visto en líneas anteriores, los únicos culpables de lucro y de descuidar sus obligaciones sagradas por buscar la ganancia económica. Si desde su expulsión en el siglo XVIII han servido de símbolo exclusivo para una tendencia generalizada en todos los niveles eclesiásticos, ha sido porque la Compañía de Jesús perfeccionó los métodos de administración patrimonial seguidos por los sacerdotes particulares y por otros corporaciones religiosas; desarrollando a una escala desconocida hasta entonces una organización económica de tipo moderno. El centro de esa organización fue en Sud América la Procuraduría de Lima donde venían los procuradores de todas las provincias aledañas. A Lima por este intermedio llegaron durante el siglo XVII y XVIII mercaderías de todos los lugares, que eran repartidas al comercio minorista de la ciudad y a las provincias del interior. El Virrey Amat, su enemigo declarado, desde antes de la expulsión, quiso en 1766 impedir este comercio público y notorio, pues los hermanos y padres de la Compañía recorrían "diariamente en los mercados y puertas de tabernas, pulperías y tiendas a mula con una tableta en la mano que les sirve para contan la moneda que perciben"1 18 . Que no se trata de una calumnia lo prueba el hecho de gue los jesuitas protestaron contra la prohibición y hasta publicaron un Manifiesto. Años después, un jesuita anónimo, descubierto por el padre Vargas Ugarte, dijo que ese comercio era incipiente y casi de puro trueque ("vender lo que les sobre para comprar lo que les falta").

4. Más graves y peligrosos que el comercio de los jesuitas fueron los métodos empleados por otros Religiosos y seculares que incurrieron hasta en delitos contra las leyes civiles. Es el caso de la usura que hemos visto condenar por Ladrón de Guevara y el Prontuario de Larraga y por la mayoría de los escritores del siglo XVIII. Los hechos constan en una averiguación judicial de 1748 ordenada por el obispo Juan Bravo de Rivero y aunque se restringen a la sola provincia de Moquegua y valles próximos, pueden representar un fenómeno más generalizado, como lo señalan algunas frases del propio obispo ${ }^{70}$. De "ese abominable y extendido pecado" aparecieron culpables, entre otros, Fray Juan José de 
Priego, Prior del Convento de Predicadores y el licenciado José Urbano Velásquez, cura de llo. Ambos en complicidad con el alguacil y el corregidor de la villa, con los mercaderes y algunos vecinos notables, habían organizado una verdadera red de préstamos entre los productores de vino, al punto que uno de los declarantes, Ignacio Díaz, dijo al pesquisidor que todos los pequeños productores de Moquegua se hallaban endeudados. Priego, Velásquez y sus colaboradores disimulaban sus manejos bajo de la forma de venta a crédito o plazo, de prendas e hipotecas en garantía de un pago sobre las cosechas futuras. Bajo esos nombres o el de habilitación y casi compañía, se convertían en intermediarios forzosos para el mercado y obligaban a que el deudor les entregase los frutos y vino a un precio inferior al del mercado, guardándose la diferencia como interés del préstamo. Si el agricultor se negaba a este arreglo, no podía enconfrar capitales en toda la región, si ya había contraído una deuda, debía saldarla en efectivo o reconocer una nueva y mayor cantidad para el pago futuro, dentro de las mismas condiciones.

No sabemos si Priego y Velásquez fueron castigados por el Obispo de Arequipa. Como en el caso de los jesuitas, de Toribio Rodríguez de Mendoza o de Cayetano León, la Iglesia parece haber sido impotente durante todo el siglo XVIII para controlar las actividades económicas del sacerdote; como tampoco pudo guiar las del laico. En uno yे otro terrenolas normas religiosas fueron reemplazádas pörulasi profánosn en un "proceso paralelo al de la filosofía y las ciencias y que anunciaba bien la creciente secularización de la sociedad civil peruana durante los siglos XIX Y $\mathrm{XX}$. Los esquemas e ideales de vida del catolicismo resultaron cada vez más estrechos para el hombre moderno y la Iglesia no pudo ni quiso adaptarse todavía más a exigencias que ni siquiera guardaban una apariencia de semejanza con el espíritu cristiano.

[Un testimonio más de la actitud del clero virreinal frente a la actividad económica se ha de encontrar en la "Cartilla Aritmética, Manual de Mercaderes y Enchiridion Enclesiástico", escrito en 1763 por Miguel de Rada, cura de Amabana (sic; ¿Charcas?). El manuscrito de 307 fojas pertenece a los antiguos fondos de la Biblioteca de Lima; del autor no conozco sino su lugar de nacimiento, el pueblo de Sorata ${ }^{80}$.

La obra estaba dividida en tres partes indicadas por su largo título. En realidad ninguna de ellas es original; el propio Rada ha confesado que su labor se había limitado a compendiar y extraer 
pasajes encontrados en numerosas lecturas. "Yo sólo e hecho el papel de la... (quemado) aveja de andar de rama en rama y de flor en... (quemado) ojeando libros... para sacar gustoso panal de su aprovechamiento". Con todo, es el único ejemplar de su clase conocido hasta hoy pues la "Instrucción que se deve observar para el establecimiento y arreglo de cualquier giro de comercio", manuscrito de la misma Biblioteca de Lima, no pasa de 16 fojas en su mayor parte dedicadas a las reglas de contabilidad ${ }^{\mathbf{1}}$.

Rada, como Olavarría, como Larriva, como el Mercurio Peruano, como el Investigador, consideraba el comercio como una práctica a la vez que una ciencia, que no podía ser confiada a la improvisación. De la misma suerte que el gramático o el abogado, los comerciantes debían conocer familiarmente ("tener en la uña") todas las reglas de su oficio y sujetar sus negocios a procedimientos racionales. El pretendía resumir en su obra todo lo que fuera necesaria para esos fines. Definiciones de los números, operaciones ejemplares, tablas de comparación entre monedas diversas, reglas para sumar progresiones y calcular la regla de tres, instituciones jurídicas, leyes, consejos religiosos, cuadros y tablas mágicos y salmos bíblicos... todo lo que al entender de Rada convenía de cerca o de lejos a las negociaciones aparecía en su libro.

En la primera parte ensayó, según sus palabras, de enconirar en las verdades eternas de los números un auxiliar lucrativo y cuo. tidiano. Comenzó con una disertación sobre el valor y origen de las monedas, indicando su conversión a las españolas y el modo de sumarlas. Después, con el mismo criterio utilitario, enseñaba la abreviación de los nominadores, las calidades de la vara, las pesas de balanza, las medidas en uso para líquidos y sólidos. Cada uno de esos parágrafos estaba acompañado de gráficos o de ejemplos ilustrativos para mejor comprensión de sus probables lectores. Rada parecía convencido que en Charcas o en el Bajo Perú, para cuyos habitantes escribía, los mercaderes manejaban deficientemente esas nociones. Un examen más atento podría hallar en muchas páginas de esta Primera Parte indicios valiosísimos sobre el desarrollo del comercio sudamericano de esa época. Es indudable que los capítulos, apartes, listas de géneros, que el autor ha incluído correspondían a una necesidad del momento. Los géneros que mencionaba por ejemplo, exóticos hoy día, fueron enentonces conocidos y usados entre nosotros. Las navajas barcelonesas, el bombací inglés, la yerba del Paraguay, el Milo cuzqueño, los hilos ricos de Flandes, el menjuí, las estameñas, las topilas de Cambray, la bengala y el lienzo de Bizco, entre docenas de nombres, son los mismos que figuran en los inventarios de la época y años más tarde (1824-1836) en los informes consulares franceses del Quai d'Orsay.

De mayor importancia es la Segunda Parte o Manual de Mercaderes, cuyc nombre serviría para designar a toda la obra. Rada 
expuso en esas páginas las reglas para vender y comprar el oro y la plata y dedicó varios capítulos a las diversas instituciones y giros de negocios. Los capítulos sobre la Bula de Cruzados, el Señoreaje, Diezmo, etc.... son en realidad pequeñas monografías que como el inédito Gazophilacio del arequipeño Feijóo, nos proporcionan una imagen aproximativa, aunque sumaria, de la economía virreinal. De todas esas disgresiones retengo las más significativas de la preocupacićn comercial de este hombre de Iglesia. Por ellas nos informamos que ya entonces, a mediados del XVIII, eran posibles y autorizadas diversas formas de asociación o compañía mercantil, como las compañías-simples y mixtas-absolutas y condicionales, intrínsecas o extrínsecas, que Rada como buen alumno de Seminario estudió y describió con la morosidad de un escolástico.

Las opiniones de Rada sobre oiros aspectos de la vida económica confirman las conclusiones del capítulo precedente acerca de los sacerdotes y el comercio. A semejanza de Rodríguez de Mendoza o todavía peor, a semejanza de los Usureros de Moquegua, Rada tampoco concedía mucha importancia a las prohibiciones evangélicas. Es cierto que en algún momento al hablar del "cambio seco" lo definió con muy débil reprobación como usura paliada; pero en general fué indulgente frente a todas las formas de lucro y de beneficio. En su capítulo dedicado al "rédito del rédito" reconocía que esa era práctica condenada por la Iglesia y por las Leyes, pero desarrollaba a renglón seguido minuciosamente las reglas que le concernían, bajo el pretexto de otras aplicaciones.

No todo en Rada fué "laico" "' "moderno"; de ahí precisamente el valor de su testimonio del transiaión. Si durante años se había "quemado las pestañas" para ofrecer a la gente del mundo un catecismo laico de mercaderes, Rada no olvidó los eternos principios religiosos: la finitud del hombre, el riesgo de la muerte, la perdición del alma. Todos esos motivos se mezclaron con los anteriores y surgieron en su obra sometidos a la idea obsesiva del Tiempo, el gran personaje de la última parte, el Enchiridión, el verdadero tema oculto presentado a manera de epílogo de todas sus disquisiciones sobre el empleo y manejo de las riquezas temporales. Aquí sus guías no fueron ya los prosaicos textos que había resumido en las primeras páginas. Las calendas, el número aúreo, los números naturales, las ruedas móviles y las ruedas perpetuas dominicales, la colección gregoriana, manos cronológicas, el cómputo y correspondencias del tiempo secular y de los tiempos religiosos, se suceden unos tras otros en el vértigo de una narración acumulativa. Al margen, versos alusivos sentencian la caduciaad de esas mismas cosas terrestres para cuya adquisición había sido escrito el libro] ${ }^{82}$. 


\section{NOTAS BIBLIOGRAFICAS}

(1) Véase: 1) Basadre, Jorge "Historia de la idea de Patria en la Emancipación del Perú" Mercurio Peruano, n. 330, 1954; 2) Pacheco, César "La emancipación del Perú y la revolución burguesa del siglo XVIII". Idem, n. 332, 1954; 3) Gil Munilla "Teoria de la Emanaipación" Estudios Americanos n. 7, 1950. Bibliografía complementaria en el mencionado artículo de Pacheco. Pacheco traza la historia de las diversas interpretaciones del fenómeno de la Independencia; desde la prolongación de la leyenda negra (la administración española como causa principal de la rebeldía) hasta las tesis liberales (influencia ideológica de Francia) y las recientes hipótesis de Giménez Fernández (la supervivencia de doctrinas tradicionales "populistas") o las de la Escuela de Estudios Hispanoamericanos de Sevilla para la que la independencia fue hasta cierto punto una sublevación burguesa. Por su parte Pacheco prefiere con José María Jover hablar no de "clase social" sino de grupo caracterizado por una misma circunstancia económica y por peculiaridades ideológicas y afectivas; sin definir previamente lo que él entiende por clase social. Señala asimismo que los protagonistas del separatismo americano fueron de extración social muy diversa y que no fue una sola la ideología o doctrina que seguían.

Una interpretación similar, en sus líneas esenciales, en el trabajo de Basadre.

En cuanto a Gil Munilla, después de estudiar las opiniones de Rodríguez Casado, Patricio Peñalver, Poras Muñoz y otros; se inclina por las hipótesis de Suárez Verdaguer: la desmembración del imperio español fue el aspecto parcial de un fenómeno más amplio, la ya tantas veces citada sublevación de la burguesía.

(2) Se habrá de evitar entonces, como lo evitamos también en este ensayo toda toma previa de posición sobre la influencia de la doctrina católica en la génesis del capitalismo. Una historia de este problema en Fanfani, Amitore "Catolicismo y protestantismo en la génesis del capitalismo". Madrid 1953.

(3) La pérdida o clausura de muchos archivos eclesiásticos peruanos me ha impedido consultar los textos de la predicación diaria que enriquecería la imagen de la cdoctrina social cátólica, estudiada aquí sobre todos a través de los sermones excepcionales, con pretensiones literarias, escritos para las grandes ocasiones.

(4) Cf. mi estudio "El Clero y el conservadorismo peruano del siglo XIX"; en prensa.

(5) Cf. Le Bras, Gabriel "Pour une Sociologie Historique du Catholicisme en France". Cahiers Internationaux de Sociologie vol. XVI. 1954.

(6) Cf. P. Macera "Religión y pensamiento moderno en el Perú del siglo XVIII".

(7) Distinción tomada textualmente de Bastide, Roger "Messianisme et développement économique et social". Cahiers Internationaux de Sociologie vol. XXXI, 1961.

(8) Cf. más adelante, por ejemplo, los pasajes de la pastoral de Echague escrita en 1825.

(9) Véase "Exposición sobre los inconvenientes que se derivan del decreto expedido por las Cortes de Cádiz para la industrialización de la caña de azúcar", Lima 1811, Biblioteca Nacional del Perú; secc. mss. D1166. La Iglesia peruana, durante el arzobispado de Gonzales de la Reguera, había favorecido a los cultivadores de viñas en su disputa con los hacendados dela caña de azúcar. Atendiendo no sólo a las disposiciones del Estado español (reales cédulas de 1693, 1714; bandos de Escobedo y Avilés; sentencia judicial de la Real Audiencia de 1766) y de 
algunas instituciones laicas (El Protomedicato), sino, principalmente, para impedir la ruina y pobreza de todos aquellos que de una u otra forma dependian del producto de las viñas. En sólo Ariquipa, como indicaba Fermín de Bernal en el informe citado, se calculaba en cercá de $100 \mathrm{mil}$ los que serían perjudicados si se concedía permiso para la elaboración del aguardiente de caña. La elaboración, por olla parte, había comenzado desde hacía mucho tiempo, según el mismo texto, gracias a los alambiques privados y clandestinos. Las decisiones de Gonzailes de la Reguera recogian otras anteriores del cpiscopaclo peruano.

(10) Ladrón de Guevara, Diego; Virrey del Peru. "Carta Pastoral..." Madrid 1712. La primera impresión deesta Carta fue de 1695 , siendo Ladrón de Guevara Obispo de Panamá. Si su autor creyó opor tuno reimprimirla, después de haber sido Obispo de Huamanga y de Quito y mientras desempeñaba el cargo de Virrey del Perú, fue sin duda porque sus advertencias las consideraba válidas y extensivas a gran parte de las colonias españolas que conocia por propia experiencia.

Sobre Ladrón de Guevara véase: 1) Peralta, Pedro de "Imagen Po-" lítica de Govierno del Excmo. ... D D Diego Ladrón de Gucvara..." Lima 1711 ; 2) Salazar, Tomás de "Respuesta por el Excmo... . D D Diego Ladrón de Guevara... a los cargos de l'esidencia..." Lima 1718.

(11) Cf. más adelante ps. 18 y ss.

(12) P. Macera, estudio sobre "La Vida sexual en el Perú duran. te el siglo XVIII Lima, 1959 (Archivos de la Facultad de Letras de San Marcos).

(13) Cf. Mendiburu, Manuel de "Apuntes histórícos", Lima, 1902 ps. 42 y ss. En 1613 según las sinodales del arzobispo Lobo Guerrero había en el Perú 48 días de fiesta y de feriado, sin contar los domingos $n i$ los días dedicados a recibimientos, natalicios reales, honras fúnebres, etc.... Algunos de esos días eran feriados para todas las clases y castas; otros exclusivos de los españoles. La Sinodales de 1640 mantuvieron' todas esas festividades. En el siglo XVIII fueron suprimidas algunas y agregadas otras de acuerdo con los cómputos de Mendiburu. Sin ctmbargo, buena parte de esas festividades (que llegaron a 71) eran consideradas como "medias fiestas" en que era licito eb trabajo. El Estado español y la Iglesia trataron de remediar los abusos y los perjuicios económicos que suponía este exceso dé díbs sin dabor (Fernando VI el Papa Benedicto XIV). En coincidencia con ellos el arzobispo de Lima, Berroeta, publicó un Edicto ( 2 de noviembre 1751) ordenando que con excepción de las festividades expresamente establecidas por el Papa, en todas las demás "sólo se deberá oir misa, pero se podrá trạbajar y ejercitar con cualesquiera obras serviles sin ningún escrúpulo de conciencia". Estas medidas y otras reseñadas por Mendiburu demuestran que la Iglesia intentó conciliar las exigencias religiosas y las costumbres tradicionales con las exigencias económicas.

(14) Ver nota (26).

(15) Es el caso de José Pezet ("Salud Pública" $E_{n}$ "El Verdadero T'eruano" Lima, 1812) quien plagió a Cantillón (Ensayo sobre la Naturaleza del comercio en general"; cito la edición mexicana, FCE 1950) casi ai pie de la letra, pero omitiendo las acusaciones de Cantillón contra el catolicismo. Sin embargo todos los argumentos y ejemplos de Pezet-Cantillón suponian esas acusaciones.

(16) Echague, Francisco Javier "Carta Pastoral..." Lima, 1825.

(if) Sánchez Rangel, Fipólito "Fragmentos de una Pastoral escrita en Miaynas en la fuga de su primer Obispo" Madrid 1825. Estos fragmentos fueron enviados a Lima para su publicación e interceptados por los "insurgentes". Probablemente redactadas en 1321. Suerte parecida tuvieron otras dos pastorales de Sánchez Rangel, fechadis en 1808 y 1820 , pues San Martín ordenó recoger la edición confiscando cerca de 600 volúmenes. Véase del mismo prelado "Pastoral Religioso, Po- 
litico Geográfico" Lugo 1827. En algunos pasajes de sus Fragmentos Sinchez Rangel puso en claro su posición frente a las jerarquías sociales:

"Tienen número las muertes impensadas al acrecentar vuestras chácaras y trapiches por vuestras embriagueces y pendencias. ¿O es posible calcular y detener entre muertes de sorpresa en el empeño temerario de haceros cavalleros y comerciantes a costas de otros, por vanidad y por llevar una vida blanda y holgazana que no corresponde a vuestra humilde esfera, abusando torpemente de los fondos agenos y de la confianza de vuestros amigos, esponiéndoos y esponiéndolos a ellos?..." "Que no querais por el mismo (medio: el comercio) y a pura fuerza ser en el mundo más que aquello que quiere Dios que seais naturalmente, conforme a vuestro nacimiento y proporciones. Como si Dios, siéndole vosotros fieles, aunque no lo seais, para ver si lo sois, no tuviera cuidado de daros lo conveniente para vuestra salvación y sustento, cuando el Señor da de comer a las aves del cielo, viste los lirios del campo, sin que aquellos ni éstos trabajen ni hilen".

(18) Idem anterior.

(19) Soto Francisco del "Reflexiones Crítico Apologéticas. "T. I. Lisboa 1751: "El mundo político es, como el natural, un armónico instrumento compuesto por varias vozes, cuya sonora desigualdad coordina la sabiduría infinita, con aquella acorde consonancia que corresponde a los altos, inescrutables fines de la Divina Providencia. Tan ageno de razón es conceptuar en este maravilloso instrumento una igualdad perfecta de fortunas, como pretender una variedad armoniosa en la perfecta unisonidad de los cuerpos".

(20) José de Santiago Concha "Cartel del Certamen del Nuevo Héroe de la Fama..." Lima 1762. ps. 16 y ss. Una variación (La Ciudad y el Cuerpo Humano) en Francisco Ruiz Cano "Júbilos de Lima..." Lima 1755; otra en、Baquíjano (El Comercio y las Venas) "Disertación histórica y política sobre el comercio del Perú" Mercurio Peruano tomo I, f. 269 y ss. Lima, 1791. En su ataque a Hobbes pronunciado en las Cortes de Cádiz Morales Duárez no atacó estas comparaciones entre el cuerpo humano y el organismo político, sino lo que él consideraba mecanicismo ateo e inmoral del Leviathan. Anotemos de paso que Hobbes fue casi desconocido en el perú como que fuera de la primera edición, en inglés del Leviathan (1651) y de la latina de 1682, las de 1678 y $179 \pm$ fueron publicadas en holandés y alemán, idiomas del todo desconocidos entre nosotros.

(21) Como lo prueban sus proyectos pedagógicos. Cf. P. Macera "La enseñanza en el Perú del siglo XVIII" Lima 1959 (Archivos de la F'acultad de Letras de San Marcos).

(22) Daquíjano y Carrillo, José "Elogio del excelentísimo Señor Don Agustín de Jáuregui..." (Lima 1781) en el Boletín del Museo Bolivariano, año I, 1929 n. 12, p. 505.

(23) El Investigador, Lima 1814 n. 25.

(24) Cf. P. Macera "Religión y pensamiento moderno. II".

(25) Argote, Romón de En "Lágrimas de Lima en las exequias... de D D Pedro Antonio Berroeta..." Lima 1776.

(26) "Traducción mandada hacer por Diego Ladrón de Guevara del discurso en francés sobre la limosna publicado en el tomo 2 de los discursos sobre la piedad". Lima 1745. Ladrón de Guevara, laico, presentó varios memoriales y solicitudes a la Iglesia y al Estado, a fin de obtener ayuda para la construcción de un hospicio de pobres. El Virrey Amat por orden y bando del 20 de Junio de 1765 hizo conocer que la metrópoli aprobaba esos proyectos (Biblioteca Nacional de Lima; secc. mss. C3955).

(27) Idem anterior. 
(28) Thimeo (Gonzales Laguna) Proyecto económico sobre la internación y población de los Andes... Por D. Juan de Bezares" Mercu. rio Peruano t. L. f. $290,1792$.

(29) Idem anterior.

(30) Liñán y Cisneros Melchor de "Carta Pastoral de Exortación..." Lima 1695. Véase también su "Carta Pastoral que escrive... a los Dueños de Chácaras, Panaderías, Obrajes y Tenerias..." Lima 1697.

(31) Berroeta, Pedro Antonio "Carta Pastoral... con ocasión de las noticias que se han participado en España..." Lima 1756.

(32) Idem 30. Confrontar con los testimonios de Manuel Antonio de Ũrismendi (1812), cura de los Atabilos Bajos y de Canta, en las sierras del Lima; y los de los redactores de El Investigador (1814). Urismend, Manuel Antonio de "Scrmón Panegírico que en honor y celebridad de la Gloriosa Virgen Santa Rosa de Santa María... dixo...." Lima 1812: "Ya el hombre actual siente sometido su espivitu a la rebelión de la carne... IVada le parece más insoportable que el yugo del Señor... ¿A qué fin aterrorizarme con los horrores de la penitencia cuando hay delicias en el mundo? ¿A qué entregarme al ayuno y la oración, quando hay negocios de más importe sobre que discurrir, empresas y proyectos que efectuar? ¿Porqué he de ser en la soledad y el retiro un miembro inútil en la sociedad?" El Investigador. "Artículo Comunicado" por el Verdadero cristiano; n. 44133 de febrero de 1814): "Lo que antes era verdad, hoy es falsedad y engaño: si antes se conocía que nuestra alma era inmortal, hoy se quiere hacer creer su mortalidad: los que se amaban como hermanos hoy se miran de enemigos: y en fin se trata de atesorar sea del modo que fuese, sin atender a las circunstancias de una vida pasagera que no presenta mas que jardines aparentes y una borachera ansiosa dol tesoro como si éste fuese con nuestro cuerpo y alma a toda una eternidad. Aquí pues, es preciso preguntar ¿cómo habrá sicio lo ganado del tesoro y en qué términos su adquisición?"

(33) Pezet ob. cit.

(34) A pesar de sus inexactiudes, no son erróneas en lo esencial las versiones escolares que hablan del "contrato de Panamá" y que oponen y reúnen las figuras del soldado Pizarro y del mercader Almagro.1

(35) Anónimo (El Judio Portugués) V'Descripción del Virreinato deí Perú "Crónica medita de comienzo del siglo XVII Rosario 1958. Edición de Boiesiao Lewin. La primera noticia sobre esta descripción (hoy en la Biblioteca de Paris) fue de José de la Riva Agüero. Raúl Porras parecía haber identificado a su autor pero no comunicó sus descubrimientos. Sus investigaciones en la Sección Protocolos del Archivo Nacionai de Tima lo condujeron a reconstruir la descendencia de un Rector de San Marcos a fines del XVI, propietario de una casa o quinta en los alrededores de Lima, una de cuyas hijas casó con el "Judío Portugués". Dintre sus libretas de notas entregadas a su discipulo Félix Alvarez Brun debe haber mayores precisiones. (36) Bravo de Lagunas, José "Voto Consultivo..." Lima 1761. Se-
gunda Edición corregida; Montero, Victorino "Estado Polftico del Reino del Perín.." Madrid 1747. Copias manuscritas de esta obra en la Biblioteca Nacional biográficas y en podex de Andrés Aramburu Men-
chaca, Referencias biográficas sobre su autor en mi estudio "Las breas
coloniales del siglo coloniales del siglo XVIII".

(37) Cf. P. Macera "La vida sexual en el Perú del siglo XVIII".

(38) El Conde de Premio Real quien obtuvo en 1807 concesión tación de mineral a los paises neutrales. Archivos del Quai d'Orsay. Fonds Pérou. I746-1823, Tomo V, fs. 53-78.

(39) Cf. P. Macera "Las breas peruanas de la colonia" Lima-1959 (Archivos de la Facultad de Letras de Sin Marcos). 
(40) Carrió de la Bandera "Descripción del Perú" Lima 1782. Mss. del Archivo de la familia Moreyra.

(41) Avellafuertes, Juan José; Intendente de Tarma Carta a su protector el Marqués de Casa Tremañes, Mayo de 1781. Mss. del Archivo de la familia Moreyra, sin clasificar. "...Digo a todos que el Rey ha declarado por noble la profesión y que si no hubiera sido minero sería un pordiosero y el hombre más abatido y avergonzado que se encontral'ía entre los de mi clase con lo que concluio este punto".

(42) Ariz, José de "Elogio del Señor Don Ambrosio O'Higgins..." Lima 1800.

(43) Feyjóo, Benito "Valor de la Nobleza e Influxo de la sangre" clel Teatro Crítico, T IV Madrid 1730.

(44) Ladrón de Guevara, Diego, vecino de Lima ob. cit.

(45) El franciscano Olavarría decía en su Discuros sobre el Comercio (Semanario Crítico, Lima 1792) : "Dios ha querido determinadamente que hubiese trato y contrato entre los hombres"; agregaba que el comercio era, o debía ser, una ciencia y una práctica. Opiniones similares en el "Elogio del Comercio" del clérigo Larriva (El Argos Constitucic nal, Lima 1812).

(46) Cf. nota 28. En el Archivo de la Buena Muerte de Lima so conservan hasta hoy los diversos expedientes a que dio ocasión el proyecto de Bezares.

(47) Rossi y Rubí, José "Análisis de la humanidad contrahida a la Caridad christiana y exemplos prácticos de su exercicio". Mercurio Peruano tomo I, f 13 . Como apéndice a la historia de la hermandad y hospital de la Caridad. Según Rossi, cuando el filósofo ayuda a otro hombre lo hace impulsado por el deber y su compasión es efímera; mientras que el cristiano obedece a un mandato divino y en el interior de su acción obra el amor a su prójimo. Rossi que es una de las figuras claves del movimiento ilustrado en el Perú ha desarrollado en otros lugares algunos de los conceptos que vemos aparecer en la ideología económica de la Iglesia. En el tomo II por ejemplo (f. 17. "Descripción histórica y Corográfica de la provincia de Chinchas y Tarija) hablando del honor, el prestigio y los méritos, Rossi indicaba que la pobreza implicaba algo más que una carencia económica; pues una de sus consecuencias era la de disminuir o derogar en el hombre - a juicio de sus semejantes- las virtudes que legítimamente poseia. Al lado, así, de la exaltación eclesiástica de la pobreza y de la aproximación de la imagen del pobre a la del Redentor, coexistía el desprecio laico, el juicio social peyorativo. De ahí que como demuestran otros testimonios, sea necesario no acordar a la predicación religiosa y las ideas e ideales que proponía la Iglesia una vigencia excesiva en el interior de la sociedad civil. Por el contrario, como expondré en otro ocasión, lo característico del siglo XVIII fue el lento desaparecer o la debilidad de los arquetipos cristianos, poco a poco substituídos por una visión utilitaria y racionalista del mundo.

"La pobreza en las cosas humanas hace el mismo efecto que las lentes inversas en los tubos ópticos: empequeñece los objetos y los confunde. A estas calidades que en cierto modo le son inherentes, la opinión tirana de los conceptos ha añadido otras más sensibles. El hom:bre pobre es necesariamente obscuro, incivil, abatido, defectuoso y por colmo de infelicidad se vuelve ridículo. No le basta el ser virtuoso para merecer el aprecio de sus semejantes, es menester que sea un monstruo o que haga milagros".

Una posición semejante a la de Rossi y a la que se expone en el texto puede encontrarse también en otro redactor del Mercurio Peruano, Meligario. Cf. "Disertación histórico ética sobre el Real Hospicio General de pobres..." MP tomo IV, f. 124. El autor seguía a Thicrs y a Feyjóo y consideraba que la caridad era una virtud necesaria y justi- 
ficable -como la pobreza- dentro de la organización jerárquica y dívina del universo. La desigualdad social era pues legitimá, más los privilegiados tenian, por encima de todos, el privilegio de su responsabilidad; eran como imágenes o sombras de Dios en la tierra. El rico era el intermediario entre la Providencia y el pobre. Sin embargo, con la prodigalidad el cristiano caritativo no debia ser confundido con el pródigo ni proteger la pereza o ahuyentar a los hombres del trabajo.

(48) En la "Fúnebre Pompa, Magnificas Exequias... a lả justa Memoria del Illmo. Señor D. Juan de Castañeda..." Lima 1756.

(49) Sánchez, Juan. Sermón San Lázaro. La limosna para Sánchez era el beneficio para el lico, pues si mediante ella el pobre recibia habitación, en cambio el rico obtenía palacios más durables en la eternidad: "Vierais en fin a la Limosna artífice aun mismo tiempo de dos palacios: vierais la emplear de suerte los primores de su arte que quando parece no traza más que un Edificio, son dos los que idca: quando parece que sólo cuyda de darle habitación al pobre, le labra también palacios al rico; porque haciendo que ambos se den la mano para su provecho, de tal modo mueve al Rico a que levante ál Pobre Hospitales en la tierra, que se sirve también del Pobre para que fobrique al Rico Palacios en la Gloria".

(50) Bermúciez, José Manuel "Oración fúnebre del.... señor.... Don Juan Domingo Gonzales de Ia Reguera. ..." Lima I805.

(51) Marimón, Juan de "Oración Fúnebre... del hermano Fray Francisco Verástegui" Lima 1767. 1759 .

(52) Del Corro, Diego; Arzobispo de Lima "Sermones..." Lima

(53) Idem nota anterior.

(54) "Traducción mandada hacer por Diego Ladrón de Guevara del discurso en francés sobre la limosna publicado en el tomo 2 de los discursos sobre la piedad" Lima 1745 , tomo 109 de la Colección Zegarra": "Por un desorden perjudicial, el comerciante, el villano y el más viİ. tiene la misma grandeza y magnificencia que el más noble y el más grande de un estado, persuadido que con la fortuna entra en una famiIia la nobleza y la grandeza".

(55) "Traducción de tres capitulos de la obra moral que escribió en itaijano el ruditísimo Duis Antonio Muratorio con el título de la cariciad Christiana en quanto es amor del prójimo". Manuscrito sin fecha en la Biblioteca de la Universidad de San Marcos (sin catalogación) Muratori recomendaba ardientemente la ayuda al pobre pero sin excesos, disciplinándola. Las reglas principales que señalaba eran: 1) no permitir que aumentase el número de pobres; 2) no proteger al ocioso; 3) preferir en la limosna a los hombres de la propia nación y dentro de ellos a los más pobres. Señalaba también los peligros sociales de la mendicidad, causa primera, a su entender, de la delincuencia.

(56) Idem nota 54 . Ideas similares en Bravo de Lagunas, José "Discurso Histórico Jurídico del origen, fundación, reedificación, derechos y exenciones del Hospital de San Lázaro en Lima...", Lima 1751.

(57) Ladirón de Guevara, Diego, vecino de Lima, op. cit.

(58) Unanue, Hipólito. "El clima de Lima", Lima 1805.

(59) Sobre la extensión de la mendicidad en el Perú no existen hasta hoy dorumentos ni estudios publicados. Podemos en cierta medida conoceria en un lugar concreto del Perú (Huamanga 1792) por un grupa die rlocumentos ( 22 peticiones de mendigantes) que pertenecen a la colección particular del canónigo ayacuchano Ernesto Navarro del Aguila. Me limito a extractarlas, sin mayores comentarios. Como podrá observarse, la pobreza y la limosna alcanzaban a grupos de muy diverso origen nijes se verá àesfiliar en las peticiones españoles, mestizos, nobles y villanos:

Algunos como el español José Escandón pedían además de una corta limosna siquiera un empleo en el Palacio Episcopal "de escaleras 
abajo". Otra peticionaria dice estar ciega "sin tener a quien bolber los ojos para ber de mantenerme ya abanzada de edad y no tener un trage como cubrir mi desnudez aun para la frecuencia de los santos sacramentos". (Margarita Pacheco). Francisca Villaverde, viuda, pedía limosna para mantener la virtud de sus tres hijas doncellas pues sólo se mantenía con "el limitado uso del Ilado que se acostumbra en el país" y que muy pocos compraban. Juana Machado, con una sintaxis mestiza de español y quechua pide sostenimiento pues se halla "mitida en un rincón sen padre ni madre" cuidando a una hermana muda. Una "humilde obeja", Jacinta Porras, viuda con crecida familia, en los mismos términos. José Gregorio Paredes, con tres hijas, decia haber buscado trabajo sin conseguirlo y que sus hijas padecian miserias "a causa de las pocas o ningunas medras que les ministran sus trabajos". Cinco hermanas huérfanas y doncellas, con la madre ciega, apellidadas Ascorga, no tenían con qué vivir desde la muerte de su padre que las habia mantenido recluídas en el monasterio de Santa Clara. Vivian de amparo en casa de su hermano y estaban en la miseria pues habían muerto también sus tias, monjas de velo negro en los monasterios de Huamanga. Doña Fulgencia Gutiérrez de Quintanilla, de antiguas y nobles famalias, pedía una limosna "correspondiente a mi calidad y estado" y hacía ver que "aunque sufro estas estrecheces (Hablo con ingenuidad y veneración) me mantengo (gracias al Señor) sin leción en la integridad como es público y notorio en esta ciudad'. Tomasa Ventura López Palomino "viuda de una de los principales vecinos" por iguales motivos demandaba ayuda. También Micaela Infanzón mujer del que fue Francisco de Barco "pues la suerte me ha conducido al mayor abatimiento e inopia después de tanta abundancia". La "humilde povre". Martina Salcedo hacía valer su petición porque "a pesar de mis indigencias y calamidades he procurado guardar mi virginal sin desviarme en cosa alguna". María Ambrosia Espinoza, vieja y enferma, pedía limosna "por los pocos días que que quedan". Por excepción hay esta vez un proveído inmediato en el oficio "Podrá atenderse". Manuela Basavilvao declaraba que vivía miserablemente con un "hilado corto" y que iba quedándose ciega "por lo que me veo precisado a mendigar por puertas". Una forastera, la viuda Felipa Randuli, enferma, rogaba "una corta limosna para que ya pueda pasar la Vida mientras los pocos días que me quedan... pues de lo contrario pereceré de hambre y mas en este lugar que todo és tangescaso aun para los mesmos del lugar como habrá quedado bien impuesto". Micaela Riva, de edad avanzada, quería limosna para sus hijas a fin de que "no se expongan con la necesidad a perder y marchitar la hermosa flor de su Virginidad". Cathalina Ponce de León no tenía "ni desensia alguna con que salir a misa", alimentaba a su abuela y vivía "retirada del bullicio del Mundo... y de su peligrosa tentación que persuaden a una Vida desarreglada". Leonardo Villaberde, español ciego de ochenta años, que no podía caminar. Una madre Isidora Soto solicitaba la limosna para que su hijo fuera recibido de Colegial en el Seminario de Huamanga. María Inés Pando, de estado honesto que junto con sus hermanas sostenía a su madre "con el corto producto que reportan las labores de sus manos". Y otros...

(60) Idem nota 57.

(61) Carrió de la Bandera, Alonso ob. cit.

(62) Borda y Orozco, José Antonio "Relación de las Reales Exequias... de la Reyna Madre... Isabel Fernesio..." Lima 1768; Baquíjano y Carrillo, José. "Disertación histórica y política sobre el Comercio del Perú" Mercurio Peruano (1791-1794); Feyjóo de Sosa, Miguel "Expediente promovido por el Director y Comisionado de la Rta de Tavacos..." Lima 1791 Mss. Archivo Nacional del Perú; Breas, sin clasificar.

(63) Le Bras, Gabriel. Artículo "Usure". En el |"Dictionnaire de Théologie Catholique..." Tomo XV Paris 1935-1951. 
(64) Ver nota (10) 1720.

(65) Larraga, Francisco "Prontuario de Theologia Moral", Lima

(66) 'Defensa de D. José Antonio Polo y Caso, escrita... por el $\mathrm{D} D$ Justo Figuerola en la causa que por apelación pende en esta $\mathrm{Cu}$ ria...", Lima 1813; ejemplar del Cabildo de Huamanga.

(67) Francisco de la Fuente "De lo bueno lo mejor, Gobierno espiritual y político...", Lima 1693.

(68) Citado en El Mercurio Peruano, I,ima 1792, Tomo I. f 102. Entre otros testimonios y para lo que concierne a España. Cf. "Representación del Real Colegio de Boticarios de la Villa de Madrid" s.l.n.f., aunque impreso del siglo XVIII. Biblioteca de la Universidad de San Marcos; sección de impresos raros. Según este informe había, sólo en Madrid, (¿hacia qué fecha") siete boticas abicrtas por religiosos de comunidades que competían con las de los laicos. Ese negocio, como cualquier otro, decía el Real Colegio Madrileño es incompatible con el estado eclesiástico. "Estando dividida la República Christiana en dos estados y siendo el Religioso y Eclesiástico, por su elevada perfección, declicado solamente a la Oración, Oficio Divino, Exercicios espirituales y cultivo del Alma, debe estar enteramente apartado de todo estrépito, oficio y cuydado temporal". "Y si a los que sirven en la Milicia Temporal les prohibe justamente la negociación y el comercio, porque no se distraygan de la vigilancia, cuidado y obligaciones de su cargo; con cuanta mayor razón, y causa se les debe prohibir a los Soldados de Cristo que se ocupen y embaracen en los negocios y ejercicios profanos".

Las Comunidades religiosas, agregaba el impreso, que se dedicaban a estas actividades económicas perdian el carácter de su instituto y podían ser comparadas a una Compañía Comercial. No faltaban entonces autores que, como se verá páginas adelante (Pastoral Ladrón de Guevara, 1712) sostenían que el negocio era permitido si se trataba de vender cosas simples y no transformadas por la industria o el artificio humano. Los Boticarios madrileños negaban la probabilidad siquiera extrínseca y levísima de esta doctrina.

(69) Salinas y Córdova, Fray Buenaventura "Memorial presentado al Rey Nuestro Scñor. ", Madria, sin fecha; probablemente de 1645.

(70) Virrey Ladrón de Guevara Op. Cit. Sobre las actividades económicas del clero colonial véanse las disposiciones del VI Concilio Limense (1772-73). En particular la Acción III, Libro III, Título I "De Vita et honestate clericorum"; caps. 13 a 16. Vargas Ugarte Rube "Concilios Limenses" Tomo II (Textos) Lima 1952.

(71) En el caso de la medicina, por razones públicas y no de provecho personal. Años más tarde, el padre Gonzales Laguna ("El Zelo sacerdotal para con los niños no nacidos...", Lima 1781) opinaba que los sacerdotes se hallaban autorizados para practicar la operación cesárea en caso de quo no hubiera otro que mejor pudiera hacerla. Seguía en ésto Gonzales Laguna, la obra del canónigo Gongamilia (Emcistercense Alfonso José Rodriguez. Para prevenir todos los escrúpulos, Gonzailes Laguna decía que al practicar esa operación los sacerdotes no pecaban contra la castidad porque "Entrando el cuchillo se equivoca de inmediato el cuerpo con el de un puerco taraceado". Anotemos que paradójicamente para despertar "el zelo sacerdotal para con los niños no
nacidos" Gonzales Laguna seguía a San Pablo (los niños son vasos de ira y contumelia antes del bautismo), negaba la existencia del Limbo y hasta parec, en sus teorías sobre la Gracia, haber utilizado sin citar la
obra de Jansenius. $(72)$ Pérez Calama, miembro de la Sociedad de Amantes del País,
romentó en su diócesis. de Quito los proyectos económicos para la construcción de barcos, la explotación del añil, la grana y la cochinilla, ctc.... Mercurio Peruano, Lima 1793, tomo IV, f. 68. Sobre Gonzales Laguna 
y su intervención en los proyectos colonizadores de Bezares véase nota $(28)$.

(73) "Arbitrios propuestos acerca de la construcción de máquinas..." 1786. Archivo Nacional del Perú, sección Minas, sin clasificar (referente al cura García). "Expediente n. 18 relativo al nuevo orden de beneficiar metales de Plata..." 1793. Biblioteca Nacional de Lima, Sección manuscritos C1099 (referente al cura Aguilar). Aguilar había propuesto su método en 1764 , pero en 1777 lo presentó como suyo en Méjico Don José Cornejo Prieto. A su Nuevo Orden, que contemplaba entre otros puntos el reemplazo de los indios por los caballos para la trituración de metales, Aguilar agregó una Cartila Instructiva. Sobre los arbitristas del siglo XVIII existe un informe inédito de Don Cosme Bueno en la Biblioteca de Rouen (Colección Coquebert de Montbert) que publicaré próximamente.

(74) "Petición de doña Juana de Escobar a fin de que se prohiba al presbítero Cayetano de León la elaboración de pergaminos", Lima 1754, Biblioteca Nacional de Lima, sección manuscritos C2317. De gran importancia para conocer el desenvolvimiento de la industria en Lima, pues indica cuales eran los "barrios industriales" de la época. Una queja similar a ia de Juana Escobar fue presentada a fines del siglo por la Perricholi contra el barón de Nordenchlift.

(75) 1786. "Petición presentada por el P. Vicente de Amil y Feyjóo...", Biblioteca Nacional de Lima; sección manuscritos C473; 1806, "Expediente iniciado por los padres de los niños de la Escuela de Desamparados...", Biblioteca Nacional de Lima; sección manuscritos D9947. Citado P.' Macera en "La enseñanza en el Perú del siglo XVIII" (Archivos de la Facultad de Letras de San Marcos). Sobre Isidro Guidiño véase Mendiburu, Manuel "Diccionario..." Lima 1876, tomo IV.

(76) "Un manuscrito inédito de Toribio Rodríguez de Mendoza". Boletín Bibliográfico de la Universidad de San Marcos, Julio 1946.

(77) "Expediente relativo a la solicitud del Dr. Dn. Joseph Fabián y Dn. Toribo Rodríguez de Mendoza a la Superioridad para que se les de amparo y registro de una veta de azogue..." 1795. Archivo Nacional del Perú: Superior Gobierno, legaio 13.

1947.

(78) Amat, Manuel de, Virrey del Perú "Memorias...", Sevilla

(79) "Usureros de Moquegua " 1748, Biblioteca, Nacional de Lima; seción manuscritos C3957. Dei año siguiente en un Real decreto mencionado por Palma en su Catálogo del Salón América, regulando los intereses legítimos y señalando las reglas para reducir los contratos a equidad y justicia.

(80) Biblioteca Nacional de Lima; sección manuscritos B147.

(81) Biblioteca Nacional de Lima; sección manuscrito F454.

(82) Escojo algunos de los versos: "Como el Vaso del OMero/ Es el Hombre fabricado/ Que en un Triz queda quebrado". "Todos los hombres por tiempo/ Faltarán y acabaremos/ Y en ceniza acabaremos". "Oh qué día será aquel/ En que seremos juzgado/ De todos nuestros pecados". "Piensa tus antiguos días/ Y con dolor de tus daños/ Teme los eternos daños". "Con tiempo haz penitencia/ Pues tienes lugar viviendo/ que no podrás en muriendo" "Tus manos que son tus Obra/ Te darán el premio eterno/ O las penas del Infierno'.

Años antes el jesuita Francisco de Enciso en su Sermón "Del Buen Uso del Tiempo" (Lima, 1710) decía: "Sí, Católicos, tan precioso es el tiempo que no se puede comprar el más mínimo espacio de él, ni con todo el oro del mundo, ni con todas las riquezas del mar, ni cuanto tienen todos los Reyes de la Tierra. Es verdad que en algún precio podrían comprarse las Pyrámides de Egipto, los Mausoleos delos Césares, los palacios de los Reyes, las Coronas de los Emperadores y también todos todos los Reinos del Mundo; pero de tal modo es precioso el tiempo que a ningún precio se pucde comprar un solo momento de él". 